\section{Revue d'ethnoécologie}

$20 \mid 2021$

Un siècle d'ethno-machins : le centenaire de la Revue de Botanique Appliquée

\title{
Inspired by Harold Conklin
}

Research on Ifugao farmers in the Sierra Madre Mountains (northeastern Luzon, Philippines)

Inspiré par Harold Conklin: recherche sur les agriculteurs ifugao dans les montagnes de la Sierra Madre (nord-est de Luzon, Philippines)

\section{Gerard A. Persoon, Jan van der Ploeg and Merlijn van Weerd}

\section{(2) OpenEdition}

\section{Journals}

Electronic version

URL: https://journals.openedition.org/ethnoecologie/8059

DOI: 10.4000/ethnoecologie.8059

ISSN: 2267-2419

\section{Publisher}

Laboratoire Éco-anthropologie

\section{Electronic reference}

Gerard A. Persoon, Jan van der Ploeg and Merlijn van Weerd, "Inspired by Harold Conklin", Revue d'ethnoécologie [Online], 20 | 2021, Online since 31 December 2021, connection on 06 March 2022 URL: http://journals.openedition.org/ethnoecologie/8059 ; DOI: https://doi.org/10.4000/ethnoecologie. 8059

This text was automatically generated on 6 March 2022. 


\section{Inspired by Harold Conklin}

Research on Ifugao farmers in the Sierra Madre Mountains (northeastern Luzon, Philippines)

Inspiré par Harold Conklin : recherche sur les agriculteurs ifugao dans les montagnes de la Sierra Madre (nord-est de Luzon, Philippines)

Gerard A. Persoon, Jan van der Ploeg and Merlijn van Weerd

1 For many anthropologists Harold C. Conklin, who passed away on February 18, 2016, was an impressive scientist. His work on a number of themes among various ethnic groups in the Philippines stands out for its level of detail, its precision, and for providing additional meaning to the observation of daily practices. He raised the level of looking at «the native's point of view ", in terms of the indigenous knowledge and practices of local communities. In doing so he became a key scientist in ethnobotany and also in the development of multi-method field work. His work in the Philippines on shifting agriculture among the Hanunóo on the island of Mindoro, and on the rice terraces of the Ifugao in the Cordillera Mountains on Luzon stands out as examples of extraordinary scholarship and have been a source of inspiration for many scholars and students in the fields of ethnobotany, environmental anthropology and linguistics.

In this article we want to draw attention to the work of Conklin and describe some of his major contributions to the study of indigenous knowledge and the agricultural practices of rural communities in the Philippines. That his work still has great relevance today is evident from ongoing scientific debates on shifting cultivation and the Ifugao rice terraces as a "living landscape». Here we describe how in recent decades, Ifugao migrants, who left their home area for a variety of reasons, started to create a new type of Ifugao living landscape in the Sierra Madre Mountains in northeastern Luzon. We do so based on our experience with supervising groups of students working with the Ifugao and on themes that Conklin had put forward in his work. 


\section{The work of Harold C. Conklin (1926-2016)}

Figure 1 : Portrait of Harold C. Conklin

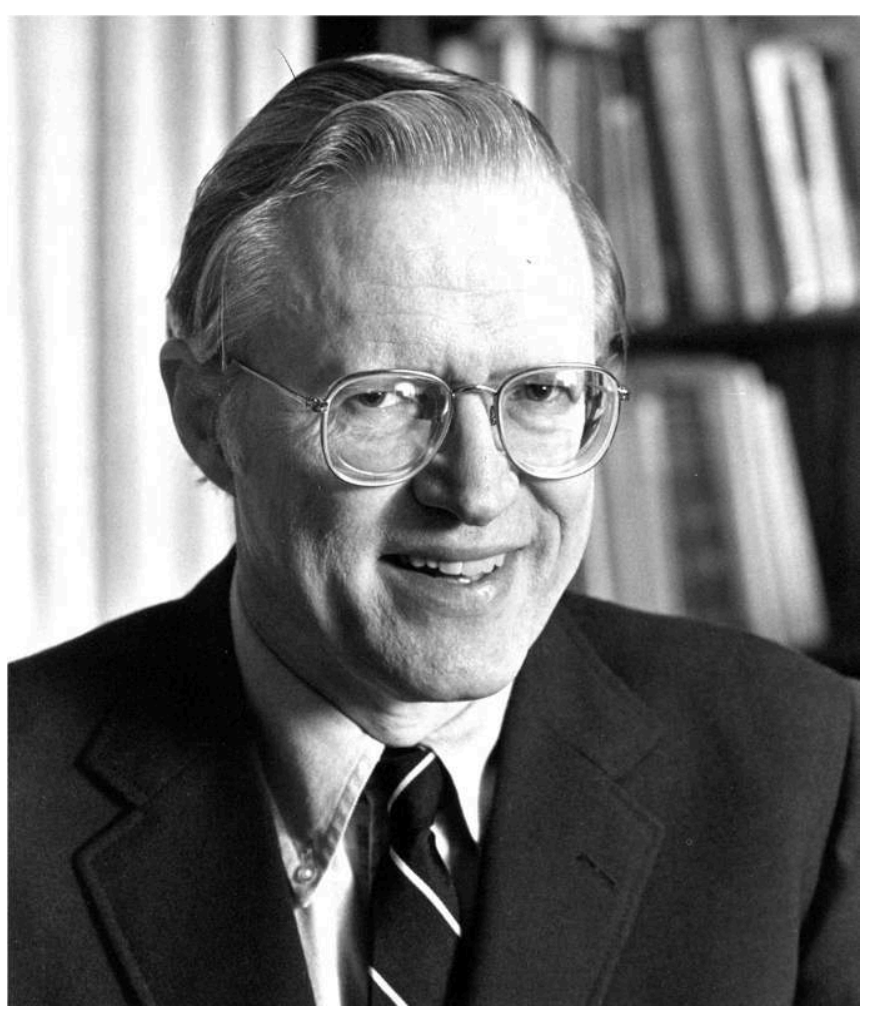

(c) Peabody Museum of Natural History, reprinted with permission

Harold C. Conklin was born in Easton, Pennsylvania on 27 April 1926. His career was strongly influenced by the fact that he joined the American army after an initial year at the University of California at Berkeley. He was sent to the Philippines in 1944. During that year he learned to speak Tagalog and when the war was over he travelled to Palawan and Mindoro, where he stayed with the Tagbanuwa and the Hanunóo indigenous peoples. He moved to Yale University to pick up his studies in anthropology again, for which he returned to Mindoro to study the local knowledge and the agricultural practices of the Hanunóo. The collected material was the basis for his doctoral dissertation titled The relation of the Hanunó culture to the plant world (1954a). This work, though it was never published, is praised for being a linguistically-informed study of a cultural knowledge system instead of just a long list of useful plants (Ellen 2016). It also formed the basis for his Hanunóo Agriculture, an impressive account on shifting cultivation that was published as a FAO report in 1957 and reprinted in 1975. This work stands out for its radically different approach to a type of agricultural land use that has often been condemned as wasteful or even irrational and that, according to many governmental agencies, should be abandoned as soon as possible. Conklin described the level of knowledge and skills that was necessary to make a living from shifting cultivation, but he also demonstrated that information on this knowledge and these skills could only be obtained by an intimate knowledge of the local language and intensive fieldwork (Conklin 1998). Through his early work he had already shown the relevance of an ethnobotanical or ethno-ecological perspective, which also was 
acknowledged within structuralist anthropology such as in Levi-Strauss' La Pensée Sauvage (1962). At a later stage this was being labeled more generally as « an indigenous knowledge system » (Brokensha et al. 1980, Warren et al. 1995, Ellen et al. 2000, Dove 2016, Dove \& Kirch 2018).

In the early 1960's Conklin decided to conduct fieldwork among the Ifugao in the Cordillera Mountains in northern Luzon, known for their spectacular rice terraces (Figures 2 \& 3). Just as in his earlier work, he started to work with a sharp eye for detail regarding the agricultural calendar and the knowledge and practical skills that were needed to build and maintain the terraces, with their stone walls built against steep slopes. At some stage he must have decided to work towards an ethnographic atlas of the Ifugao landscape for which he needed high-quality photography and new cartographic technologies, including high-resolution aerial photos in combination with very detailed knowledge of the situation " on the ground " (Conklin 1968). The scope of this effort in terms of methodological challenges and the incredible amount of work, given the available technology at that time, is impressive. The result, his Ethnographic Atlas of Ifugao, published in 1980, is still a landmark in environmental anthropology.

Figure 2 : Conklin in pond field in Banaue with Huwan Binong from Bayninan

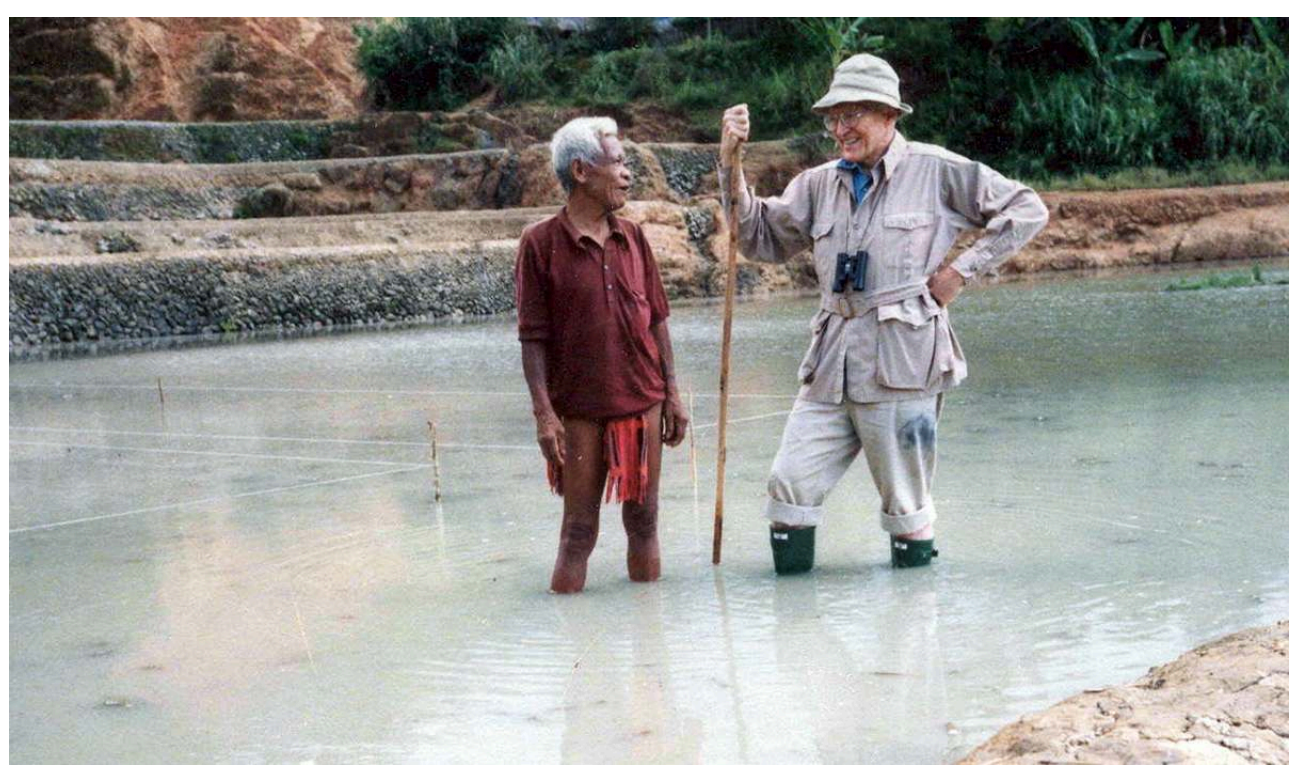

(c) Peabody Museum of Natural History, reprinted with permission 
Figure 3 : Rice terraces in Banau shortly after the planting season

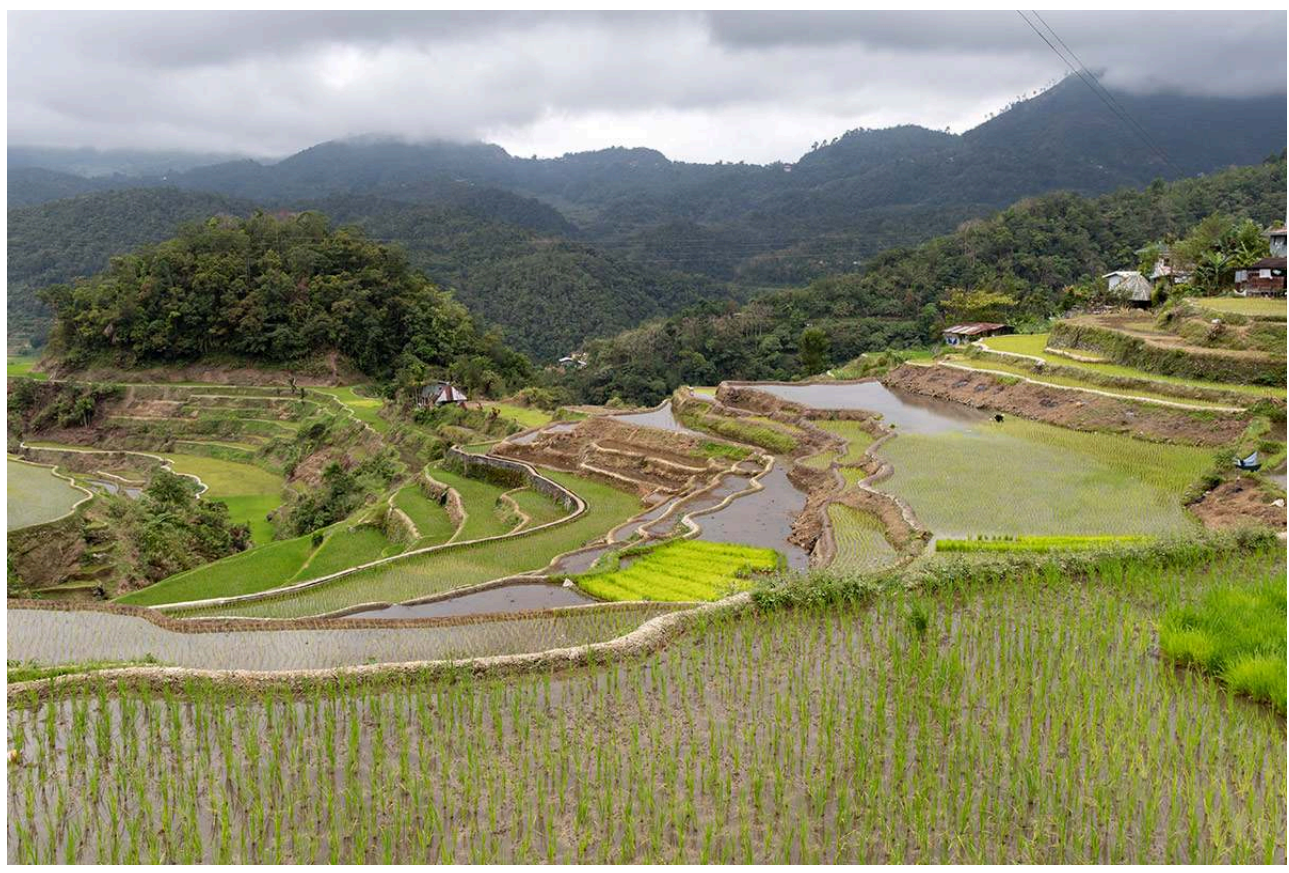

(c) M. van Weerd

5 In addition to these key publications, Conklin also wrote about other topics, including colour classification, speech, folk taxonomy, pottery, kinship and music. Some of these articles are published in a book titled Fine Description, Ethnographic and Linguistic Essays that was edited by Kuipers \& McDermott (2007). The title Fine Description is consciously chosen to describe Conklin's work: his ethnography is «fine " both in the sense of " fine detail » or « thick description » as Geertz has labelled it, and it is also "fine art " (Frake 2007). The articles are grouped together under a number of themes such as « the world of plants ", "modes of communication », and "agricultural knowledge » and they are introduced by colleagues and students from the U.S.A., France, and the Philippines, who were obviously impressed and influenced by Conklin. They include well-known names like Charles Frake, Clifford Geertz, Nicole Revel, and Michael Dove. Finally, mention must also be made of Conklin's activities as a museologist and a scholar of material culture. He contributed a large number of objects to the collections of various museums such as the American Museum of Natural History and the museum of the International Rice Research Institute (IRRI) in Los Baños in the Philippines, where varieties of rice grown by indigenous peoples like the Ifugao and the agricultural tools used in the cultivation of this crop are kept. The Ifugao Museum in Banaue, in the heartland of this ethnic group, also holds a number of objects collected by Conklin.

\section{Shifting cultivation}

6 Though the articles mentioned above and the other activities by him are quite interesting in themselves, the most important and lasting influence of Conklin's work is most likely related to the study of shifting cultivation. It is not exaggerated to state that, through his detailed and in-depth study of shifting cultivation as an integrated agricultural system, including the wealth of ethno-ecological knowledge, and the cultural values on which it is based, Conklin fundamentally changed the general 
perspective and the research agenda on this topic. The systematic approach to this type of land use, with attention to a wide range of topics, has inspired numerous scholars and students. His approach has also to some extent modified the rather negative attitude of policy makers and government officials to this type of land use. Through the systematic study of shifting cultivation as an integral system, it became clear that very often there is not sufficient attention given to the specific characteristics of particular agricultural systems. In many cases, easy generalizations are made about these systems on the basis of which policy measures are proposed and implemented. In many countries, shifting cultivation is condemned as a destructive system of land use, wasting valuable natural resources and causing various environmental problems. That is why it should, according to many government officials, be replaced by permanent types of land use (Van der Ploeg \& Persoon 2017).

7 Any serious scholar who wanted to study this form of land use had to take notice of the way Conklin had laid down a structured research agenda to carefully describe and analyze this agricultural system, thereby avoiding easy simplifications and generalizations (Conklin 1954b, 1961). Explicitly or implicitly, numerous researchers have stepped into his footsteps and jointly they have contributed to a more balanced perspective on shifting agriculture and forced government officials in many countries to take a closer look at such systems before condemning them as "irrational » or «backward». It has been argued that Conklin's work never directly addressed policy makers in the field of agriculture or criticized them for making decisions that were not based on a sound understanding of the systems of shifting cultivation. However, by presenting insightful descriptions of such systems without explicit political messages, the persuasive power for improving decision making may have been at least as big (Dove 2007). In the Philippines a whole range of social forestry policies have, implicitly or explicitly, made use of Conklin's insights, including those related to the country's indigenous peoples. Among these are for instance the Community-based Forest Management (CBFM), the Integrated Social Forestry (ISF) and the Certificate of Ancestral Domain Claim (CADC) programmes (Bernardo \& Snelder 1999).

In terms of the far-reaching inspiration his work has engendered in relation to shifting cultivation, special mention should be made here of an initiative started by the Canadian scholar Malcolm Cairns, a couple of years ago. In a series of books, each with its own specific focus, he has, as a very energetic editor, brought together a large number of experts on shifting cultivation. The focus of the books has been on Indigenous Knowledge (Cairns 2007), on Environmental Change and Forest Conservation (2015), on Shifting Cultivation Policies (2017) and on Farmer Innovations and Best Practices among Shifting Cultivators (in press). Three of these books, each with 800-1000 pages, have already been published and the fourth one is in press, while another one on "animals in shifting cultivation systems » is being planned. Together they read like an extensive encyclopedia on shifting cultivation with numerous case studies in addition to more theoretical contributions. It is no wonder that one of these volumes (Cairns 2017) contains a special chapter In remembrance of Harold C. Conklin, written by Michael Dove, to recognize his stimulating role in studying shifting cultivation.

\section{The Ifugao rice terraces}


Figure 4 : Ifugao settlements in the Ifugao homeland and in the foothills of the Sierra Madre

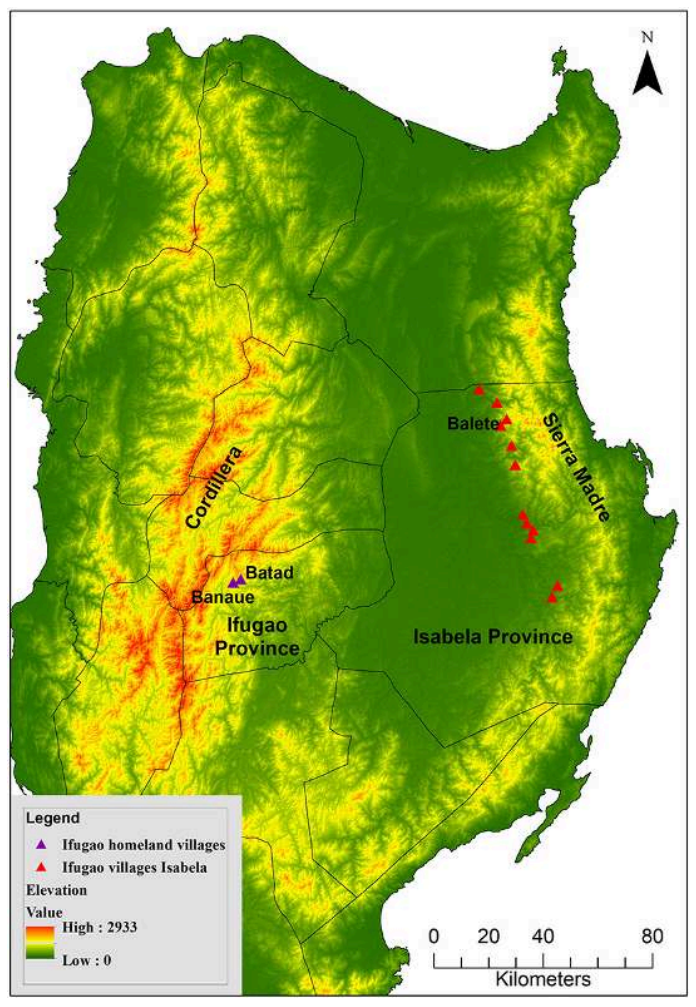

(c) M. van Weerd

9 In relation to Conklin's work on Ifugao, and in particular his Ethnographic Atlas of Ifugao, there are a number of interesting ongoing academic debates. They include the issue of the age of rice terraces and what it means for local people that the terraced landscape has been declared a World Heritage Site by Unesco in 1995.

Since the "discovery " or the first reports about the rice terraces in the early $19^{\text {th }}$ century by a Spanish priest, there have been speculations about the age of the terraces (Scott 1974). In 1973 the rice terraces of Banaue were declared as a National Cultural Treasure by the government of the Philippines. In the reports for the nomination of the terraces as a Unesco World Heritage Site, it was claimed that they are at least 2,000 years old. The nomination was awarded in 1995 on the basis of three of the ten criteria for World Heritage Sites: 1 . the terraces are a dramatic testimony to a community's sustainable and communal system of rice production; 2. the rice terraces are a memorial to the history and labour of generations of small-scale farmers; and 3. the rice terraces are an outstanding example of land use that resulted from a harmonious interaction between the people and their environment (Figures $5 \& 6$ ). The World Heritage Site status refers in particular to five terrace clusters in different settlements: Nagacadan, Hungduan, Mayoyao, Bangaan and Batad (Figure 7). All of them are Ifugao settlements and there can be no doubt that Conklin's Atlas has played a decisive role in this selection, in spite of the fact that other ethnic groups in the Cordillera Mountains also built rice terraces, some of which are as impressive as the ones constructed by the Ifugao. The total area of the rice terraces in these clusters is estimated at 10,324 ha (Calderon et al. 2009). Since the inscription as a World Heritage Site, officially known as Rice Terraces of the Philippine Cordilleras, the claim of their age of 2,000 years has been maintained (Unesco 2021). 
Figure 5 : Rice seedlings. Sprouting traditional rice seeds in Banaue

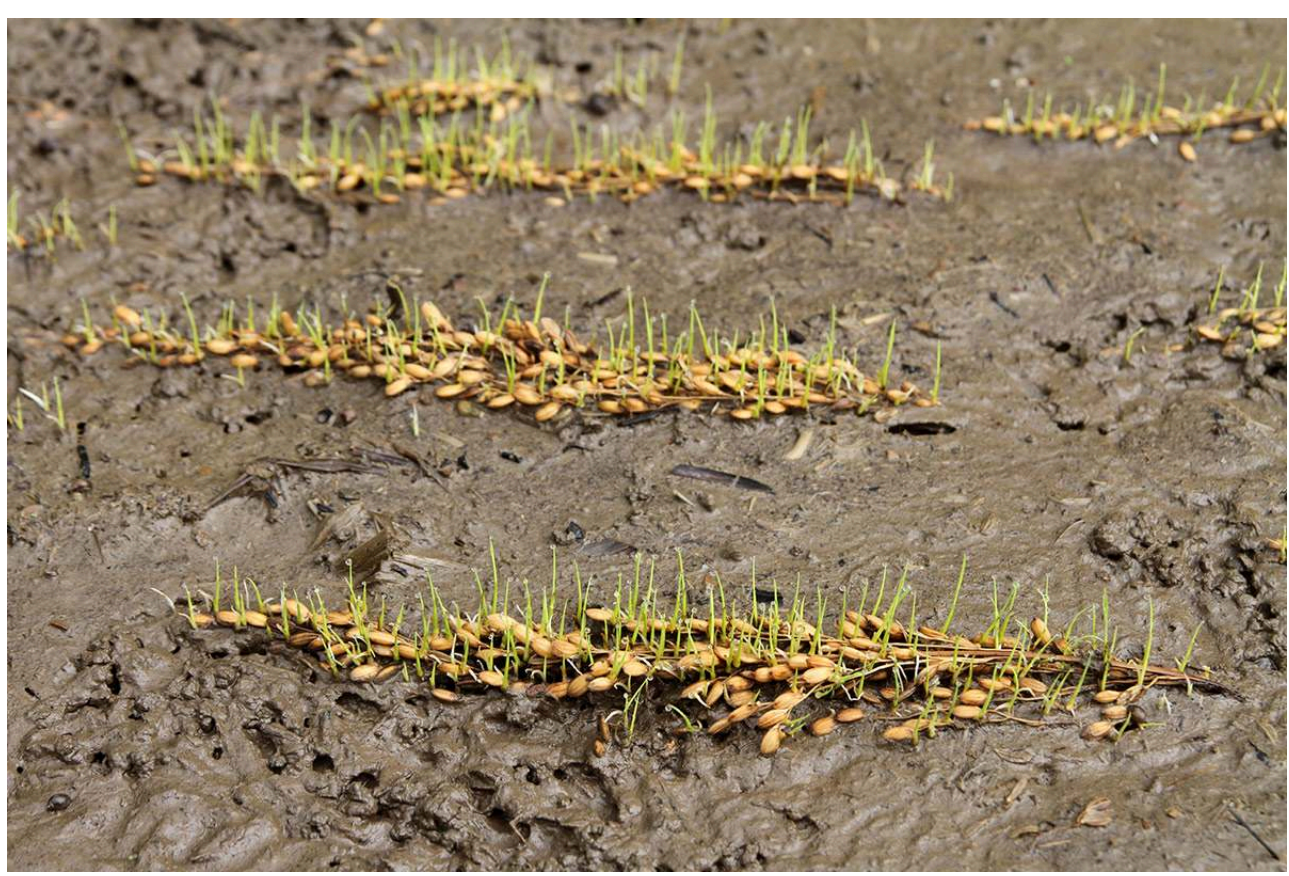

(c) G. Persoon

Figure 6 : Planting rice in Banaue

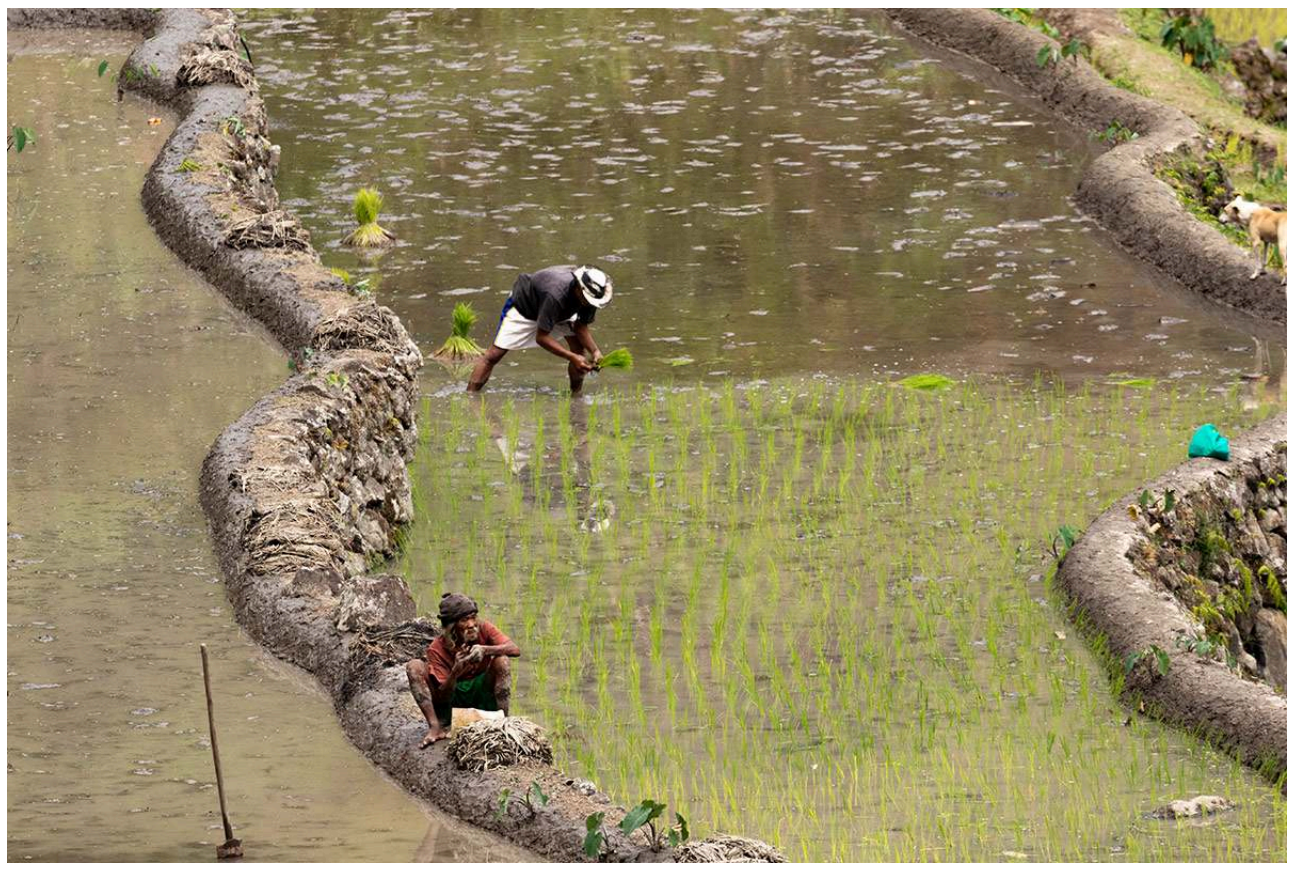

(c) M. van Weerd 


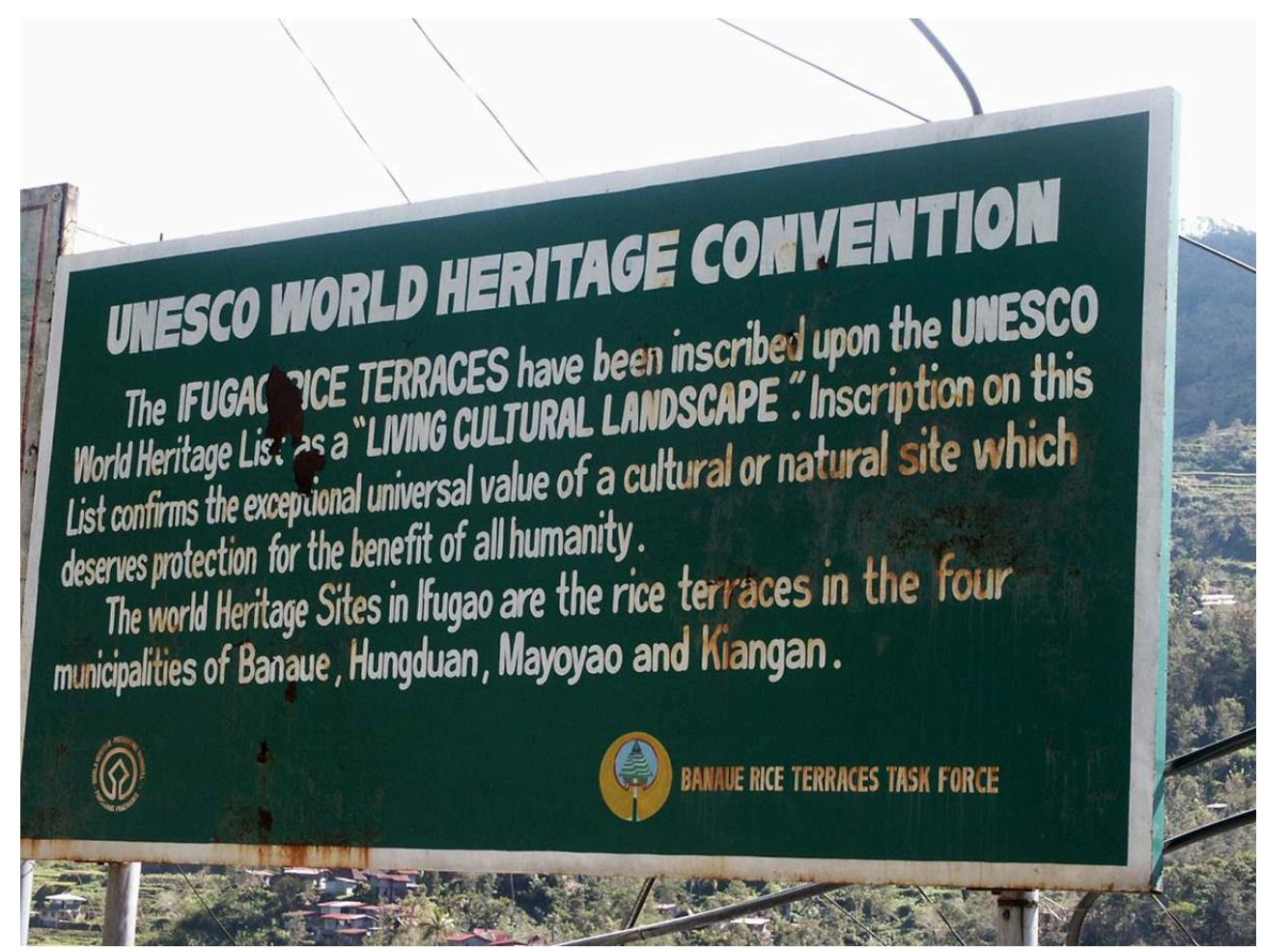

(c) G. Persoon

11 However, scientists of various disciplines have reached different conclusions regarding this point. In these discussions linguists, historians, archaeologists, botanists and anthropologists, each on the basis of their own disciplinary research methodologies, have come up with arguments against such a «long history model». Conklin was among the first to provide radiocarbon samples from the region and expressed serious doubts about the ancient origin of the terraces that was suggested by earlier authors. He also suggested that the rice terraces were most likely pre-dated by terraces on more gentle slopes for the cultivation of taro. Historians have put forward evidence that the Spanish colonizers pushed the Ifugao into the interior of the Cordillera Mountains. Recent publications by archaeologist Stephen Acadabo (2012, 2013, 2015 and Acadabo et al. 2019) have contributed a lot to finding answers to questions about the history of these spectacular landscapes on the basis of sound archaeological research at multiple sites, including also experimental archaeology. His findings, like those of others, suggest that the rice terraces are not more than a few hundred years old and that their construction must be related to the impact of the Spanish colonizers. Just like Conklin, Acadabo focuses not only on the terraces but on the entire agricultural complex of the Ifugao, as an interdependent system, which also includes swidden fields, managed forests and home gardens. In addition, attention is paid to the role of livestock, including the raising of pigs, chickens and the water buffalos that are used in the terraces (Conklin 1980, Druguet 2010, Acadabo 2012, 2013, 2015, Acadabo et al. 2019).

\section{Living in a heritage landscape}

12 As part of an integrated agricultural complex, the terraces are also subject to change. Farmers make decisions about the types of crops they want to cultivate, and when and 
how they want to do that, and also on the amount of labour they can invest in the maintenance of the terraces. As early as the time of the inscription as a World Heritage Site, it was clear that the level of maintenance of the terraces was insufficient. Parts of the terraces were overgrown with weeds, and some of the stone walls had collapsed, causing small landslides at times of heavy rainfall (Figure 8). By 2001 the threats were so serious that the site was put on Unesco's list of « World Heritage in Danger ».

Figure 8 : Damaged rice field. Lack of maintenance of the rice fields causes landslides and erosion

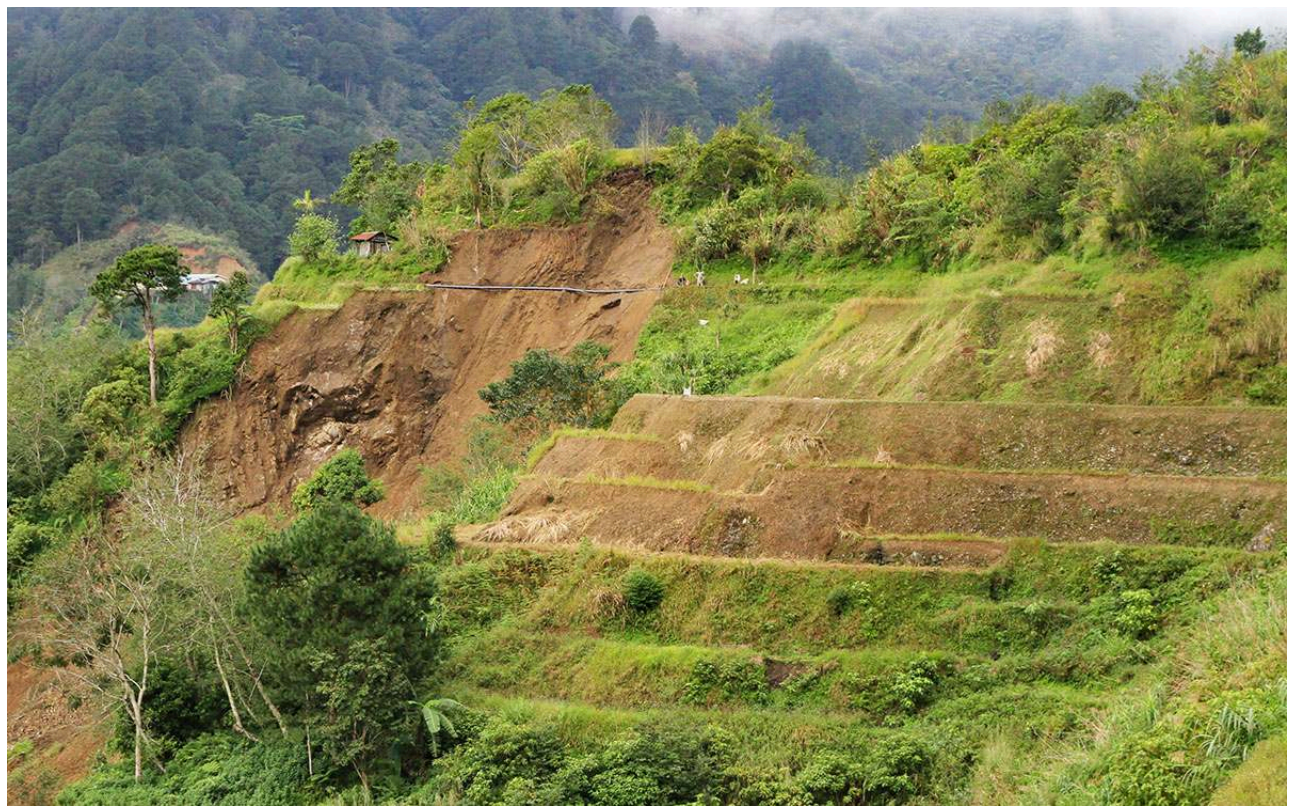

(c) G. Persoon

13 As these sites are one of the iconic hotspots of tourism in the Philippines, the national government, through its Department for Environment and Natural Resources (DENR), was prepared to set up a large-scale plan for the maintenance and, where necessary, for the restoration of the heritage landscape (DENR 2008). Foreign donors, in particular JICA, the Japanese agency for development aid, the European Union, the Asian Development Bank and the FAO were prepared to support this plan with multi-million dollar projects and expert knowledge. Based on all these efforts, the rice terraces were taken off the list of « World Heritage Sites in Danger » in June 2012, but it is clear that many of the threats are far from over (Unesco 2012).

These plans and projects, and in fact the declaration of the terraces as a World Heritage Site itself, were based on a perspective on the terraces that they never had in the eyes of the Ifugao themselves. In the course of history, the terraces were constructed through the work and skills of individual farmers, or small groups of them. Terraces are also owned by farming families and there had never been a kind of supervising organization at the landscape level. The collective actions of individuals and small groups that were necessary to construct and maintain the terraces resulted over the years in landscapes that had grown organically and that generated the admiration and interest of outsiders. It was at the landscape level that the projects aimed to restore the terraces. In so doing, the projects did not pay sufficient attention to the causes of the lack of maintenance that led to the damage: the lack of maintenance was the result of decisions of individual farmers. Apparently some farmers had lost their interest in the 
terraces, or could not mobilize sufficient labour to conduct regular maintenance work. With new opportunities to generate income in the tourism business (run a hostel, work as a wood carver or act as guide), some were willing to give up rice farming. Some farmers had changed to other more profitable vegetable crops such as cabbage and carrots, which do not need to grow in terraces and do rather well on non-terraced slopes. New high-yielding varieties of rice, the result of the Green Revolution, disturbed the more uniform rhythm of the activities related to the cultivation of rice such as maintenance of the terraces and irrigation canals. Young people also left the area to pursue further education or employment in Baguio or Manila. Others heard about the availability of arable land in the sloping hills of the Sierra Madre Mountain Range on the eastern side of the Cagayan Valley. As a result, there was simply not enough labour available to do the necessary repair work. Another "disturbing" factor in the traditional landscape is also the construction of small houses and hostels, with galvanized metal roofs and «hollow block architecture». These buildings do not fit with the claim of an "ancient heritage landscape » and do not contribute to the photogenic landscape that tourists would like to see (Figure 9).

Figure 9 : Expansion houses Banaue. New houses, hostels and shops are constructed amidst the rice terraces

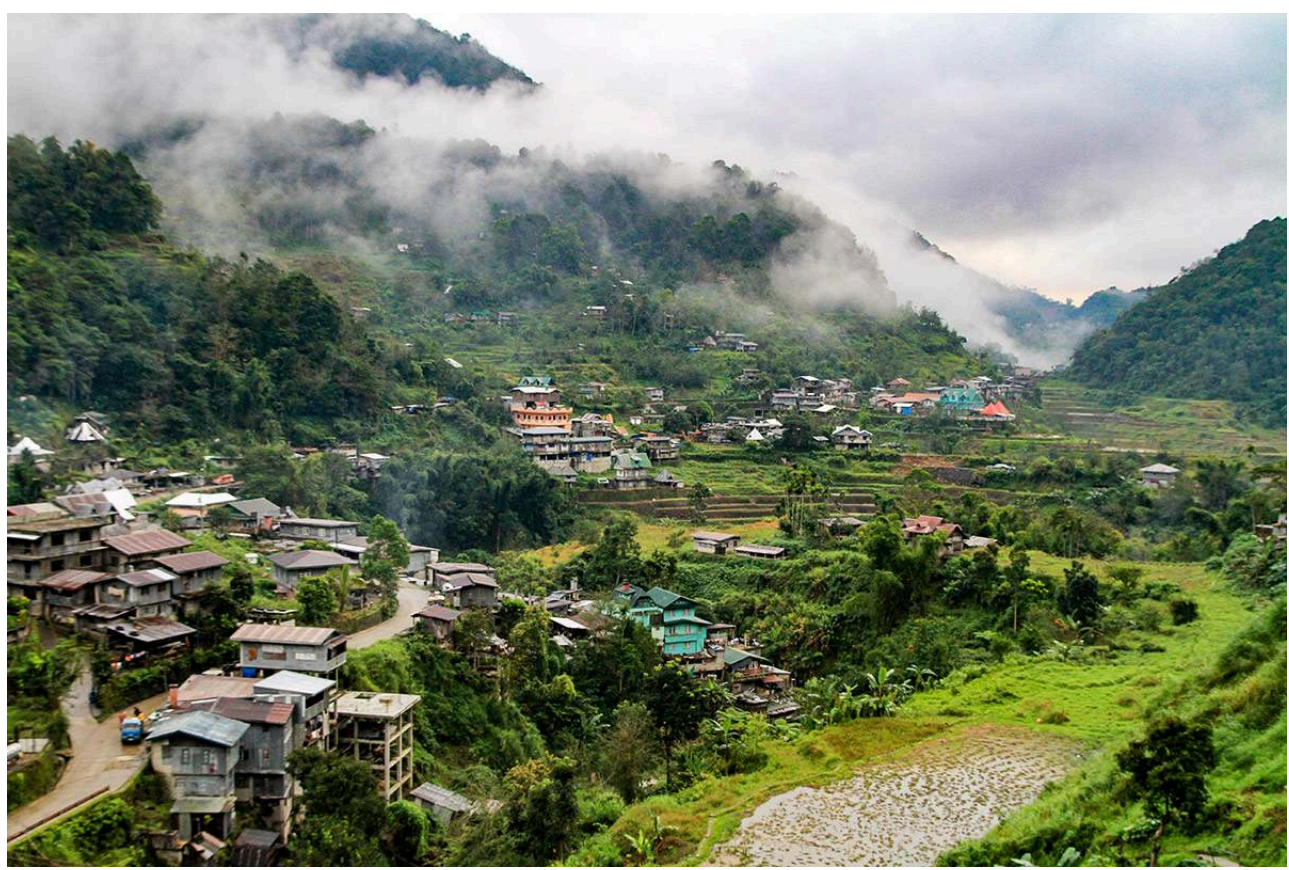

(c) G. Persoon

In addition to the economic and labour problems, there are also more technical agricultural issues. One of them that has occurred in recent years is the impact of the giant earthworm (Pheretima sp.), which is reproducing more rapidly when there is less water in the terraces (Aspe 2020). As a result of the introduction of new high-yielding varieties of rice, with increased input of fertilizer and pesticides and the more differentiated need for water in the terraces, the giant earthworm has caused serious damage to the terraces by burrowing deeper into the soil during the dry periods. It leaves holes in the soil and terrace walls through which water seeps out. Eventually this may cause the cracking of walls, leading to erosion and landslides on the steep slopes. 
These are problems for which coordinated action is needed beyond decisions of individual farmers (Calderon et al. 2009, Bantayan et al. 2012, Santiago \& Buot 2018, Aspe 2020).

Various types of interventions, including financial mechanisms, have been proposed to support the farmers in the necessary maintenance work (Calderon et al. 2009, Cagat 2018). Raising fees from visiting tourists in addition to governmental support has been one of the suggestions. Another is the idea to transform rice-the core type of food that played an important role in Ifugao life and religion - into a commodity for which there is a commercial market as « heirloom rice » (Glover \& Stone 2017) (Figure 10).

Figure 10 : Drying heirloom rice. Traditional rice has become a commercial product as " heirloom rice ", sold to tourists and urban supermarkets

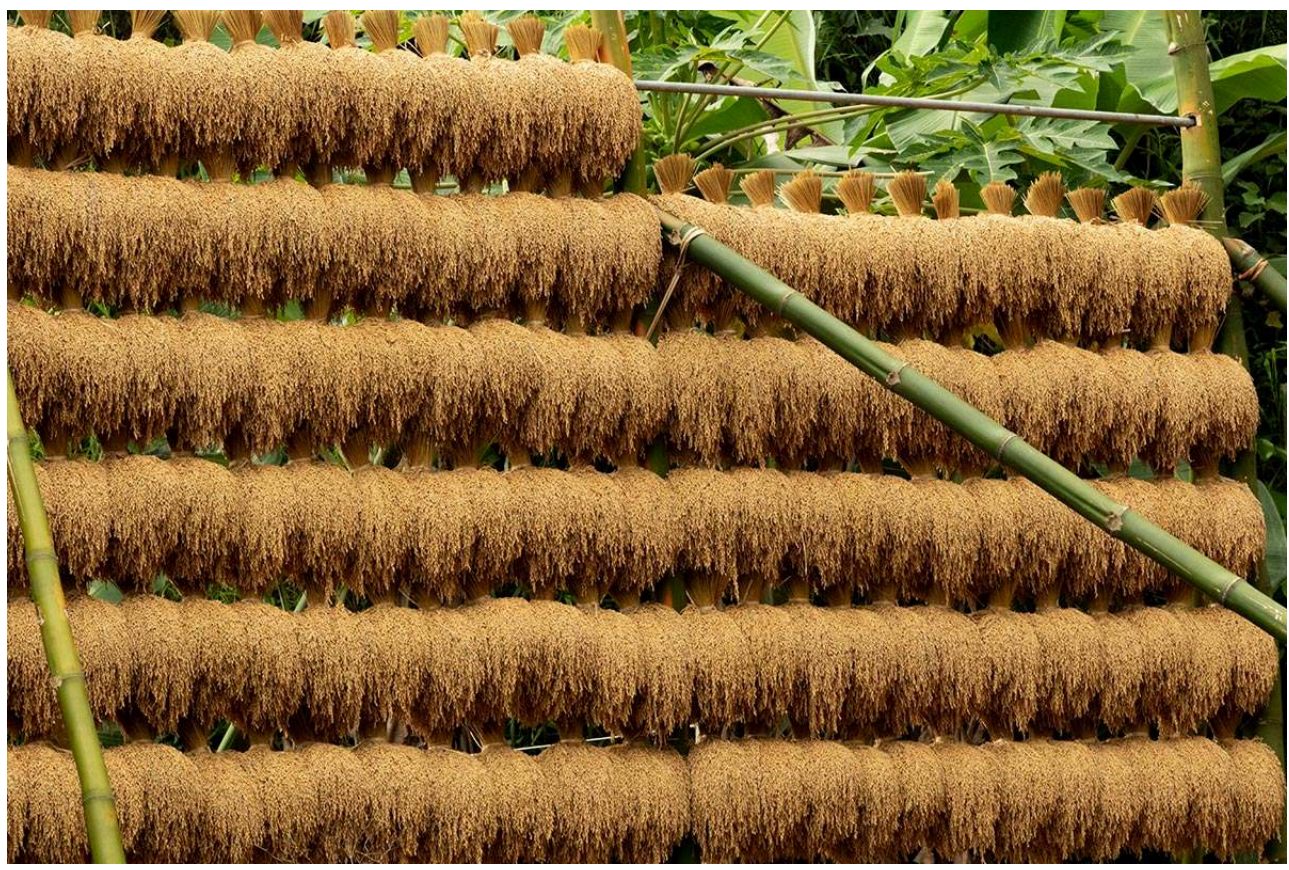

(C) M. van Weerd

The large-scale projects initiated by the government and funded by foreign donors have had a big impact on the farmers, including those whose terraces were not part of the clusters that were included in the World Heritage Site. Instead of looking at the terraces as a part of an integrated agricultural system owned and run by farmers, it started to become primarily an "object of Outstanding Universal Beauty", like a "Monument", that was threatened and that was in urgent need of protection. In the past the entire rice terrace system was rooted in Ifugao culture and identity. In the new process of landscape protection and management the idea was lost that the terraced landscape was above all a living cultural landscape, created, as Conklin had phrased it: "Only by constant repair, extension, restructuring, and the dynamic recycling of resources has the present landscape been achieved and maintained." (Conklin $1980: 38$ ).

\section{Fieldwork and ethnography}

Ethnography is considered to be the basis of anthropology. Observing and listening to what one sees and hears in the field is the starting point of getting to know the cultural 
and social life of groups of people anywhere in the world. By many anthropologists, Conklin is considered to be among the best fieldworkers the profession has ever known. The level of detail, precision and specificity, based on an intimate knowledge of the local language, is key to his ethnography (Geertz 2007). In his Atlas Conklin summarizes the research process:

" It is based on, but not limited to, a long period of intimate study and residence in one community, knowledge and use of the local language, and the employment of a wide range of observational and recording techniques, including direct participation in everyday activities and a greater emphasis on work with individual members of the society than on secondary sources or survey data ». $(1980: 1)$.

19 In his entry on "ethnography " for the International Encyclopedia of the Social Sciences (1968 and reprinted in 2007) he elaborates on the techniques and attitudes of the researcher: flexibility, curiosity, patience, experimentation and a whole range of verbal techniques for question-response sequences. Apart from the familiar ethnographic and anthropological research techniques, he made use of techniques that were rather new at that time, like aerial photography, photogrammetry and ethnographic mapping making use of the knowledge and perceptions of the local community to draw the socio-cultural landscape. It should also be mentioned that in his ethnographic fieldwork he not only strived for a high level of detail and precision in terms of qualitative information, he aimed for a great deal of exactness in quantitative terms as well. More than many other fieldworkers, he wanted to know exactly how many days of work it took to produce one ton of rice. He measured the length of the irrigation canals and the width and the height of the stone walls of the terraces. He counted the animals that were used in rituals. By doing so he avoided the usual contrast between more qualitative or more quantitative fieldwork. He recognized the merits of doing both to write high-quality ethnography.

To a large extent core elements for « doing ethnography " have not really changed since the time of Conklin's early fieldwork. Textbooks of research methods for anthropologists and social scientists still contain the same topics. But many new elements have been added, like those dealing with ethical issues, the range of potential biases while doing fieldwork, the co-production of research data with informants, and, what is nowadays called the "positionality " of the researcher. In terms of research tools, much has been added to the pencil and the notebook, and the simple camera: advanced recording devices and various kinds of digital communication. Nowadays informants themselves also avail of these kinds of devices. Fieldwork is no longer a clearly marked period in the research process with a beginning and an end, but can be extended over internet long after the ethnographer has left the field. But in spite of all the modern changes, many of the key aspects of fieldwork have not really changed. A sharp eye for making observations, curiosity, patience, commitment, language and verbal skills to achieve deeper levels of knowing and understanding are all still skills necessary to be able to write high-quality ethnography. One should also have an open mind towards what other disciplines can offer in terms of research methods and technology. There is more to be learned from works that have all these elements in them, than through reading textbooks on research methods. In that sense, many of Conklin's publications are still highly inspirational.

21 An example of this is offered by a recent interesting article by the Norwegian anthropologist Remme (2021). He indicates a number of almost « hidden » aspects in Conklin's Atlas, that many readers may have overlooked or not noticed explicitly and 
that are relevant to some of the current anthropological debates. Remme stresses, among others, how Conklin, though focusing on the importance of rice, referred to the terraces as "pond fields", and not only as « rice fields ». He did so because he realized that the terraces were much more than just places to grow rice. They are assemblages of life forms, all of which are important for their productivity and for understanding how the Ifugao relate to the variety of plants and animals in them (weeds, mudfish, snails and other mollusks, etc.). The same holds also for the multiple rhythms and temporalities that are behind the entire Ifugao landscape and its management (terraces, woodlands, swidden fields, and settlements), and that are distorted by changes in the varieties of crops that are grown or by changes in the ritual cycles that guided the traditional agricultural cycles, as a result of conversion to new religions (Remme 2021).

\section{Ifugao farmers in foothills of the Sierra Madre Mountain Range}

In 1987 Leiden University, through its Institute of Environmental Sciences, started a long-term joint research and education project with Isabela State University at the Cabagan campus in Cayagan Valley. The aim of the project was to study the full range of human-environment interactions in the Sierra Madre Mountains area (Figure 4). The research was done by Filipino and Dutch staff members and students. The programme also included quite a number of PhD projects. Over the years some 250 Filipino, Dutch and other international students worked together in interdisciplinary teams to study a great variety of topics, ranging from the dynamics and the impact of large-scale logging operations, to issues of land rights and reforestation projects (Pasicolan 1996; Van den Top 1998; Aquino 2004). Every few years a conference was held during which the results of the previous period were presented (Van den Top \& Araño 1992, Snelder \& Bernardo 2005, Van der Ploeg et al. 2003, Van der Ploeg \& Masipiqueña 2005, Masipiqueña et al. 2009, Persoon et al. 2009). A number of projects focused in particular on the Agta, the indigenous hunter-gatherers in the Sierra Madre (Minter 2010, Buenafe-Ze et al. 2016). There were also more biologically oriented research projects. And since the «rediscovery " of the Philippine crocodile in 1999, many student teams also worked on various aspects of the ecology of this animal, which was previously thought to be extinct in this area. Very soon conservation initiatives were developed for which the cooperation of the local people was absolutely necessary (Van Weerd \& Van der Ploeg 2012, Van der Ploeg 2013).

In the wake of large-scale logging operations in the Sierra Madre, numerous migrants came from all over the Philippines in search of arable land. Many of them also combined small-scale logging with shifting cultivation. Soon, however, it became clear that one particular group of migrants had a different strategy. They were searching for unoccupied small valleys and ample water resources to construct paddies for wet rice cultivation (Figure 11). They also established small settlements of several families where they constructed a type of house quite different from those of many other migrant families in the area. It turned out that many of these farmers were Ifugao who had migrated from the mountainous Cordillera to the foothills of the Sierra Madre. In sharp contrast with the steep slopes of the mountains in their home area, some of the valleys along the tributaries of major rivers had relatively gentle slopes. Constructing 
the terraces for the rice paddies required far less effort in this area, as stones were abundantly available in the nearby riverbeds and, compared with the surface of the rice fields, less construction work was necessary (Figure 12). Their presence automatically drew attention to the cultural and agricultural background of the Ifugao. The wealth of information found in Conklin's atlas, not only in the text, but also in pictures, maps, and other ethnographic material, was a source of inspiration for the students and their Filipino and Dutch supervisors.

Figure 11 : Ricefield at forest edge. Near Diwagden, in de foothills of the Sierra Madre, Ifugao have constructed rice terraces at the edge of the forest

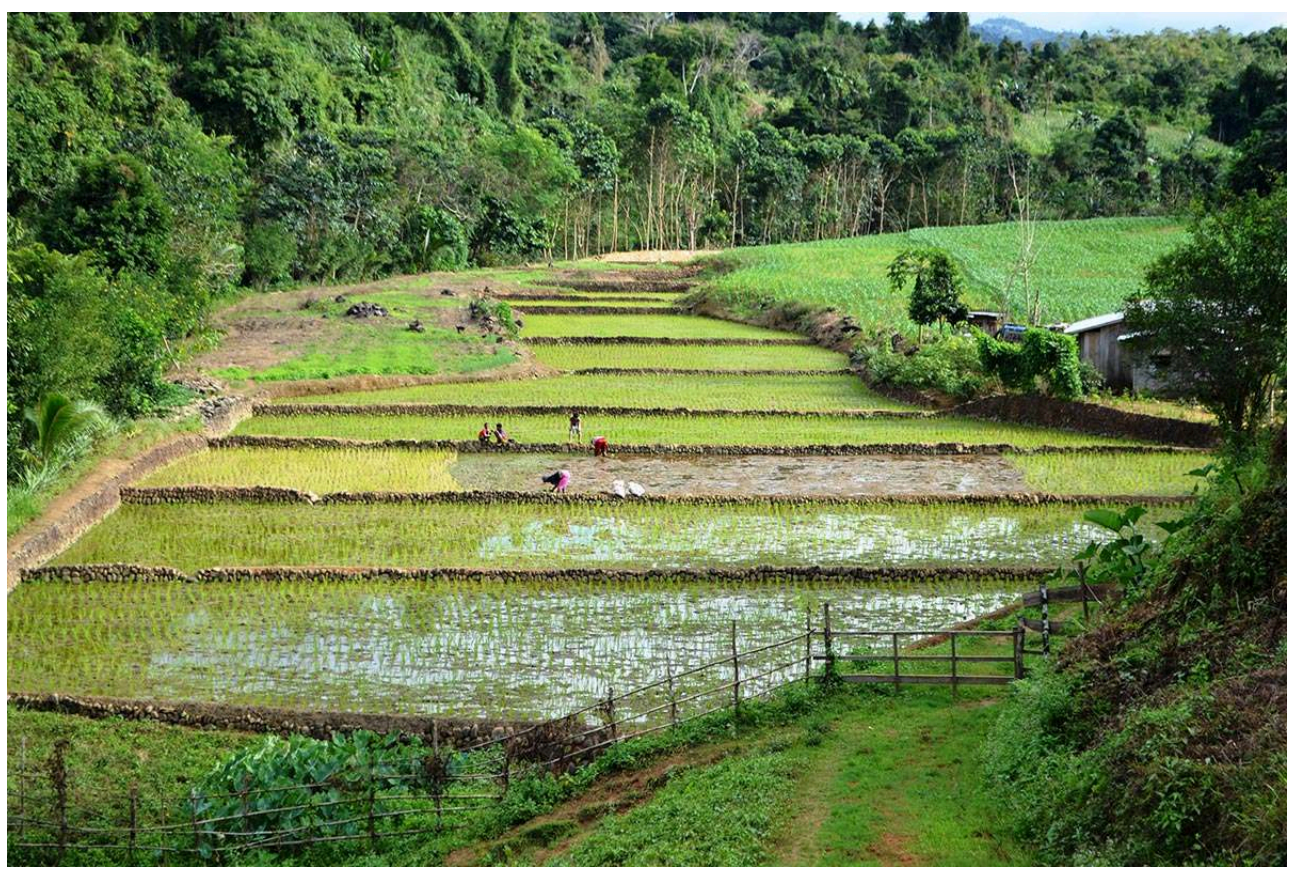

(C) J. van der Ploeg 
Figure 12 : Construction of rice fields is the Sierra Madre is less labour intensive compared with the Ifugao homeland

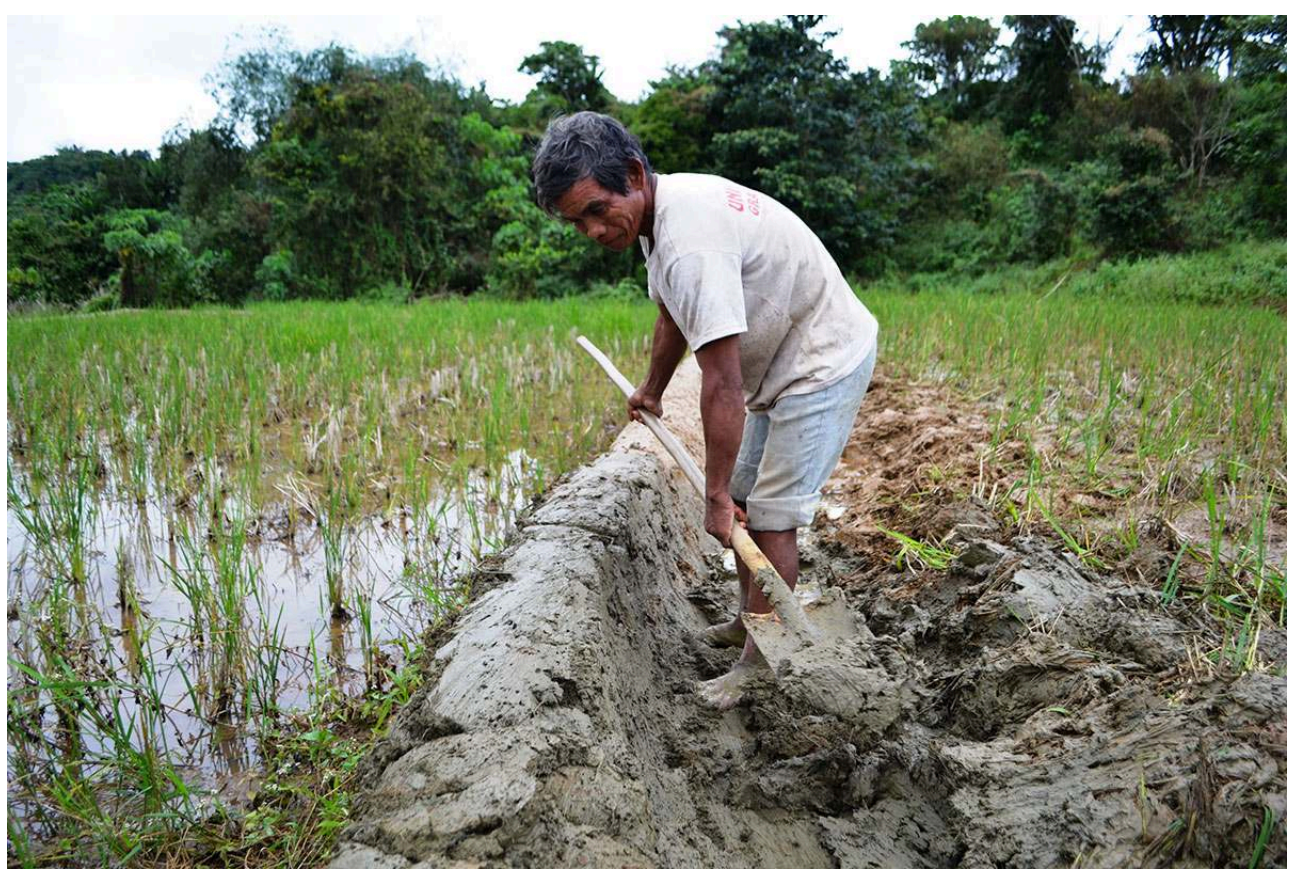

(c) J. van der Ploeg

After a number of smaller research projects, it was decided in 2007 to organize a six weeks' summer course for 15 Filipino/Dutch student pairs who were going to study various aspects of the culture and agriculture in 15 Ifugao migrant settlements in the area. A questionnaire was developed that was to be used by all student pairs to collect general information on the Ifugao villagers. In addition, each pair of students also selected a specific research topic on which they would focus in particular. The questionnaire included general demographic questions but it also paid attention to the migration history of the villagers. Other sections dealt with the modes of livelihoods of the villagers, the types of agricultural activities they engaged in, their use of forest resources, and their relations with governmental agencies and with non-Ifugao farmers. There was a special focus on cultural aspects such as language use, religion, and relations with family and relatives in their area of origin in Ifugao Province. Students were also asked to make a map of the village and a transect of the area, indicating slopes and types of vegetation.

Individual students also selected a specific topic about which they would look for information in greater detail. These topics included farming practices, crops and markets, drinking water, land ownership, beliefs, ethnic identity and material culture, including housing. After the fieldwork all pairs of students were asked to write a short report on their settlement with general information and a report on the specific topic on which they had focused, for which students could use the information collected in all questionnaires. All short reports were then edited and bundled in a booklet from which a substantial part of the information below is taken (Van der Ploeg et al. 2007).

Though the fieldwork was limited in time and the students were relatively inexperienced, the information they were able to collect was quite interesting. It generated a general picture of Ifugao farmers making a living in the foothills of the Sierra Madre Mountains, with possibilities for comparison with migrant farmers from 
other ethnic groups or with Ifugao in their home area, either on the basis of literature or through additional fieldwork. The cooperation between Filipino students and the Dutch (or other international) students, usually with different disciplinary backgrounds, worked quite well.

The settlements were all established in the late 1980s or 1990s. The Ifugao had migrated to this area after the hostilities between the Philippine army and the guerilla movement of the New Peoples' Army (NPA) had become less, following the People Power revolution of 1986 that ousted dictator Ferdinand Marcos. Though the Cagayan Valley is quite densely populated along the banks of the Cagayan River, the transition zone between the intensively used area adjacent to the main river and the foothills and the forest at higher elevations in the Sierra Madre Mountain Range was sparsely populated. The distance between the eastern boundary of the Ifugao homeland and settlements in the foothills of the Sierra Madre is only about $100 \mathrm{~km}$ in a straight line, and takes about a day by public transport, partly over small mountain roads, followed by a long stretch over the Maharlika highway, and finally over former logging roads and foot paths. The extensive grasslands in this transition zone were mainly used as pastureland for extensive grazing and some shifting cultivation. In the forested area lived small groups of Agta, the indigenous people of the Sierra Madre. The logging activities, which had started already in the 1950s, were really booming in the late 1970s (Van den Top 1998). Most of the valuable trees at the lower elevations had been removed by the late 1970's, leaving behind a vast unoccupied logged-over area, accessible through logging roads. This turned out to be an ideal site for new migrants searching for arable land. For many Ifugao, just like for migrants from other ethnic groups who lacked sufficient land in their home area, this offered new opportunities. The remaining trees could be cut, and with the use of fire the vegetation was cleared in order to start upland farming.

In those days the fertile land was often bought through informal transactions from the indigenous Agta communities for extremely low prices or small amounts of products. Through a process of chain migration more and more Ifugao started to head for this area. While looking for a suitable place to settle, they would first of all look for a good source of water supply and a landscape that would allow for the opening up of forest fields but also for constructing terraces for wet rice cultivation. Compared with the Ifugao homeland, the foothills of the Sierra Madre were far less rugged in terms of steepness and length of the slopes. This allowed for the construction of irrigated rice fields with far less labour investment relative to the amount of land irrigated. Over the years the small houses built with wood, bamboo, bark and with grass-thatched roofs were improved with more solid construction materials like sawn planks and beams, and galvanized metal roofs (Figure 13). Just like everywhere else in the Philippines, a small basketball court is to be found in each of these settlements. 
Figure 13 : Ifugao house

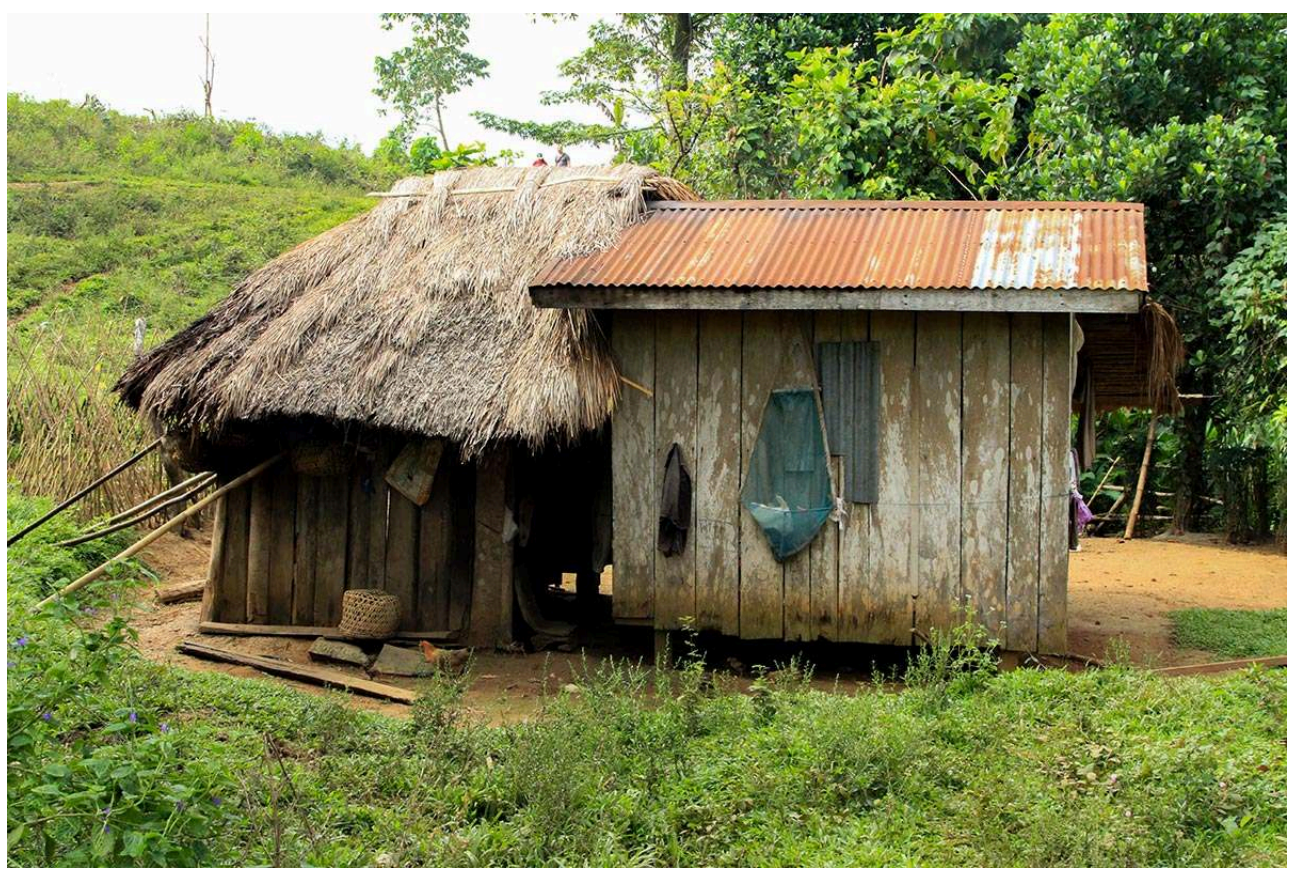

(c) G. Persoon

29 In terms of irrigation, the landscape in the new sites was very different from the homeland. Here relatively flat areas could be selected at a short distance from the source of water. In Ifugao the terraced landscape was developed over a long period of time, with the construction of new terrace fields above those that already existed. Management of irrigation water had become a very important aspect of agricultural life. Coordinated action among the farmers was necessary to ensure a fair distribution of the available water through an elaborate system of irrigation canals with hundreds of inlets and outlets on a single slope. Lack of maintenance of upland terraces could have a negative impact on those downhill, through erosion and landslides. The need for water depended on the stage of the rice crop in the cycle of cultivation. In the new settlements the terraced fields could be much bigger. There was no need to build high walls with stones, and there were only few other farmers with whom the distribution of the water had to be discussed. All Ifugao who were interviewed stated that construction of the terraces was much easier compared to the hard work in the homeland.

The area available for creating swidden fields was also quite extensive. Wet and upland rice were of course familiar crops for the Ifugao to cultivate, but soon they learned that corn, cassava and bananas could be turned into valuable cash crops generating money for all kinds of expenses. As a result, the agricultural calendar in the Sierra Madre is quite different from the one in the Ifugao homeland. While some farmers still use traditional rice varieties in the new areas, other have shifted to new high-yielding varieties, or they combine cultivation of rice with that of corn or cassava. Preparing the fields is often done with the help of water buffalo, locally known as carabao (Figures 14 \& 15). The animal is also used to bring the harvest downhill to a site where it can be picked up by a trader. The farmers stated also that nowadays they grow a greater variety of crops compared to what they used to do in their homeland. The range and timing of activities related to the cultivation of banana is of course radically different from the rhythm of annual crops like rice, and corn or leguminous plants like mung 
beans, cowpeas and green pea. An important perennial crop is also the betel nut palm from which betel nuts are harvested. Chewing the nuts in combination with some lime is an old Ifugao tradition for men and women, just as in many other Southeast Asian communities.

Figure 14 : Carabao plowing

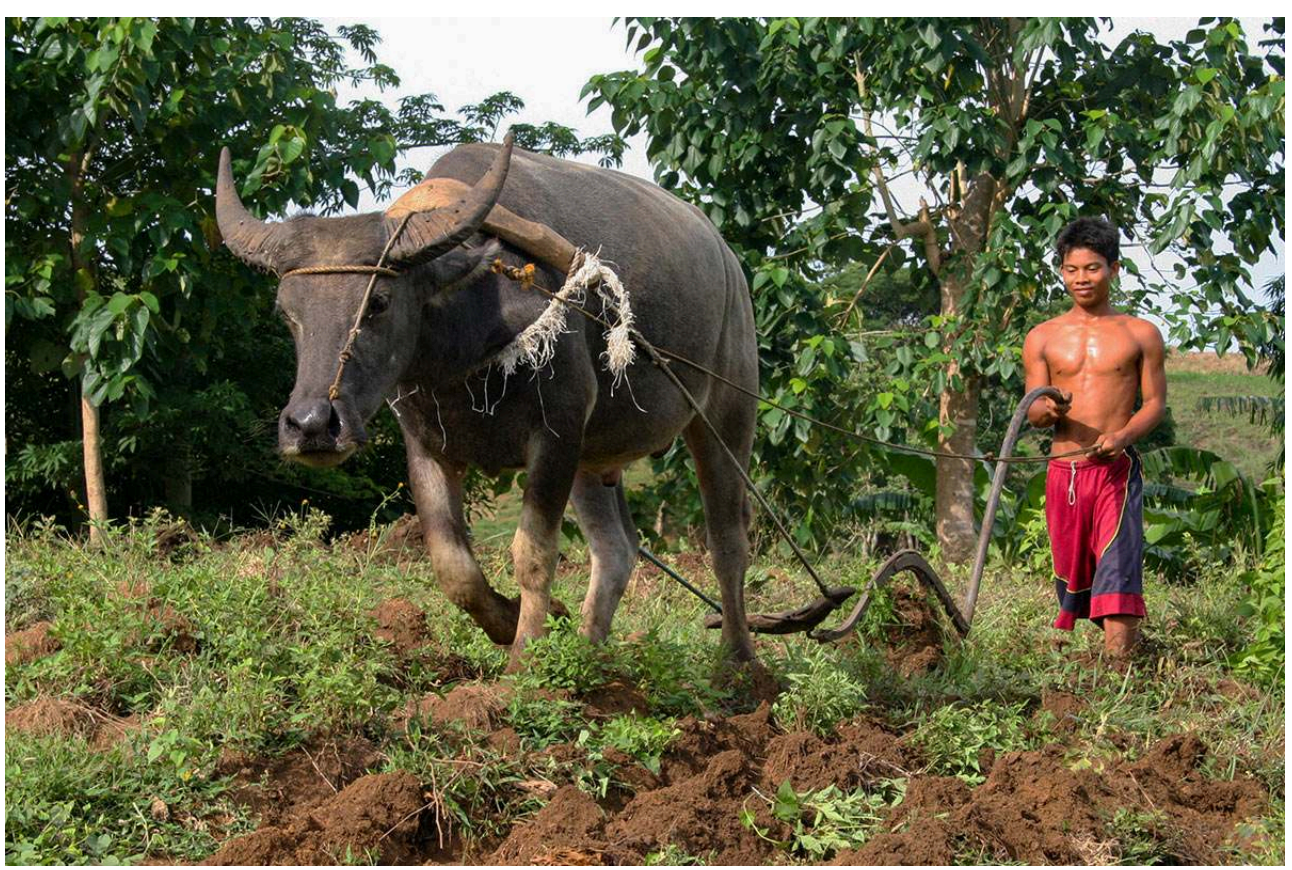

(c) G. Persoon

Figure 15 : Carabao washing

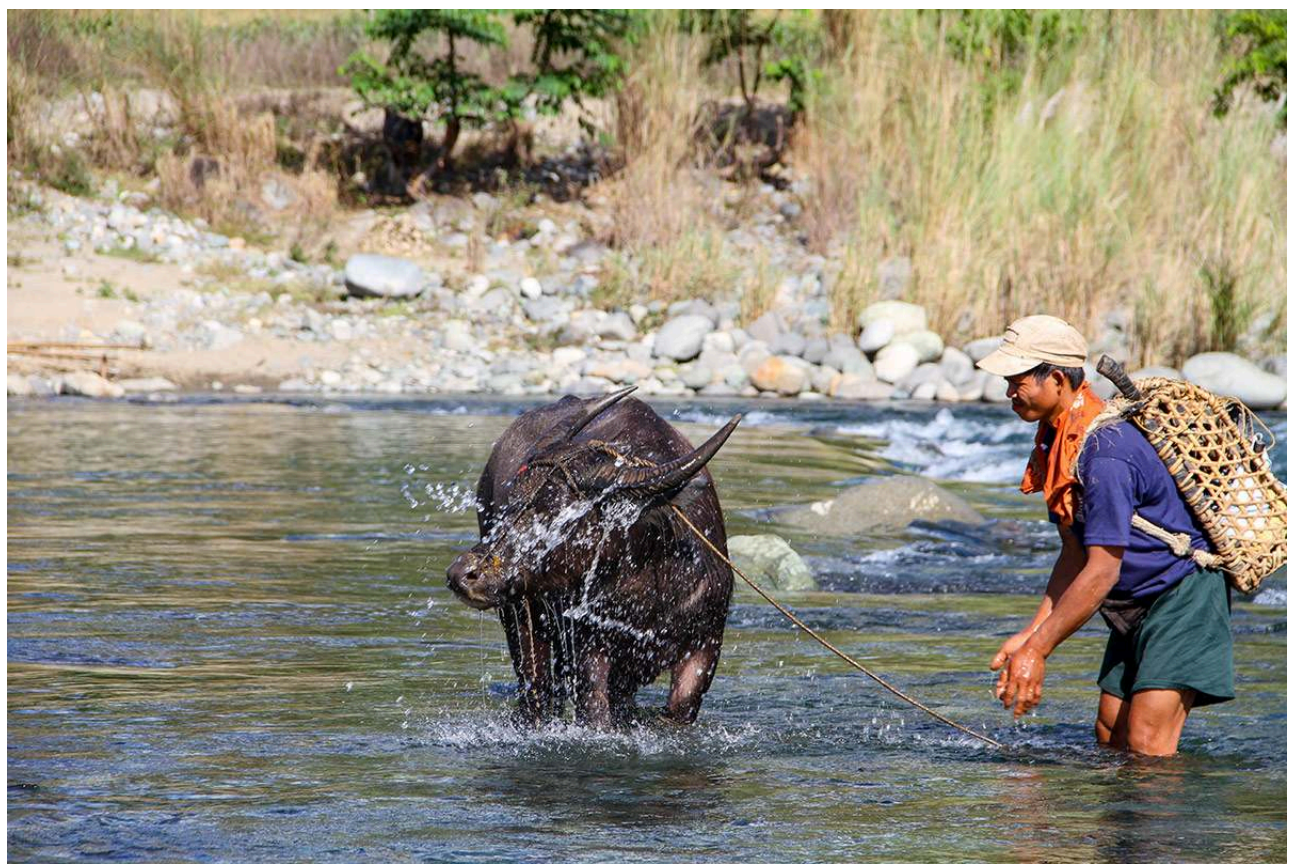

(C) J. van der Ploeg 
The 15 settlements that were selected for fieldwork were all relatively small. Some of them were exclusively occupied by Ifugao, while others were more diverse in ethnic composition. Most of these settlements were located a few hours' drive from the main road along the Cagayan River. Usually these former logging roads were in bad condition during the rainy season, making them extremely muddy and slippery. The houses in the settlements were relatively simple and made of wood and bamboo with galvanized metal roofs. In a few cases Ifugao had made the effort to construct a traditional Ifugao house with a grass-thatched roof. But apart from these exceptional cases the Ifugao houses did not really differ from those of the other migrant farmers.

The relatively close proximity of these villages to the logged-over forest and the relatively intact forests of the Sierra Madre Mountains offered an opportunity that was not available at the same scale as in their home land: small-scale commercial logging. Though cutting of trees for house construction, wood carving or household tools was also done in the Ifugao homeland in privately owned woodlots, the forest resources in this new area were far more abundant. With the use of a chainsaw and a water buffalo, it was possible to cut the remaining trees, saw them into beams or planks and pull them out of the forest over small muddy paths to a site where they could be collected by a middleman using a so-called jeepney to bring them to the towns and cities along the Cagayan river (Figures 16 \& 17). Though cutting trees for commercial purposes was officially forbidden, this form of small-scale logging was widely practiced as the demand for hardwood from the flourishing furniture industry and the booming construction activities was rather large. It offered many people who were living on the fringe of the forest, like the Ifugao, an additional and attractive source of income.

Figure 16 : Carabao logging

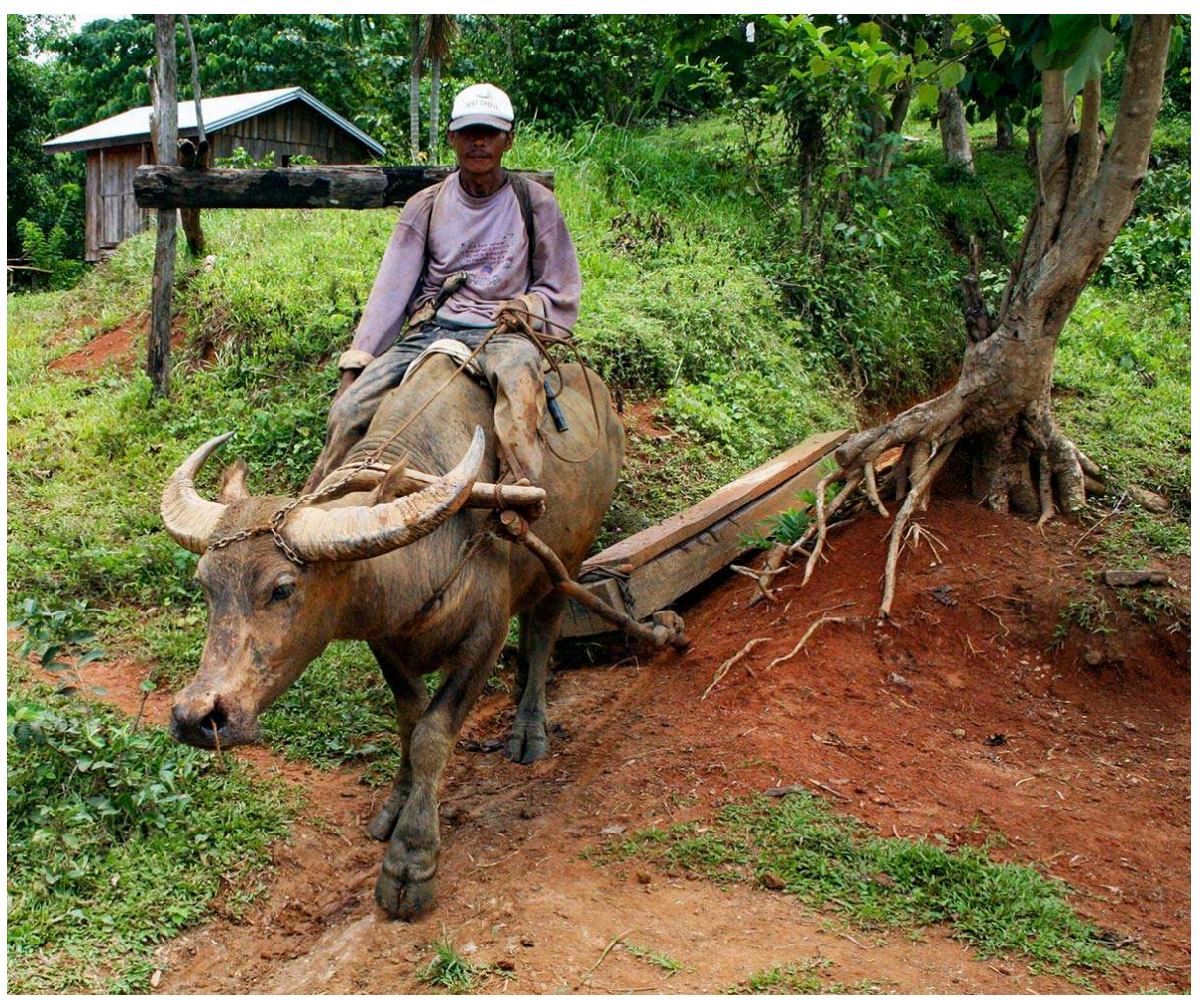

(c) G. Persoon 
Figure 17 : Carabao Charcoal

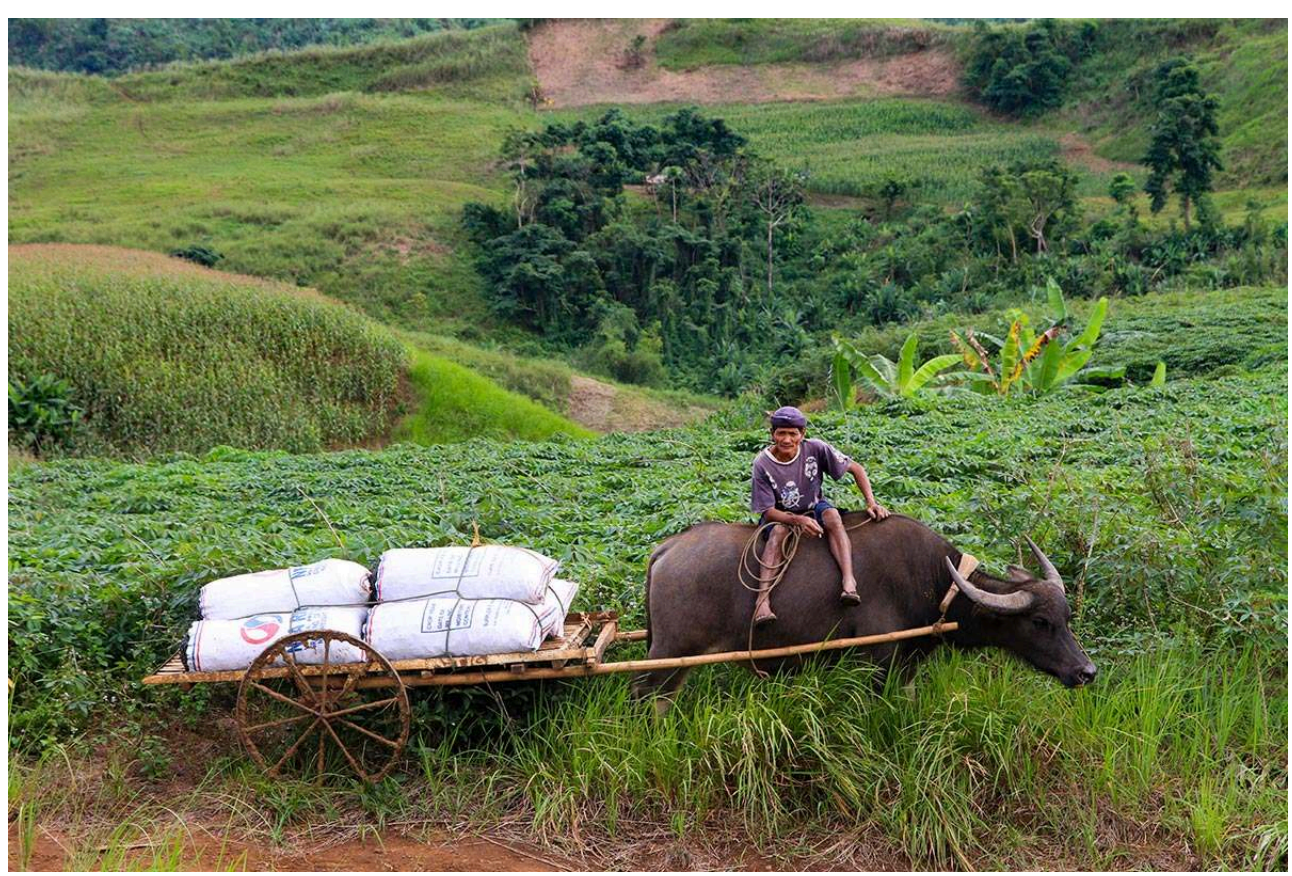

(c) G. Persoon

Another option that was more widely available for the Ifugao migrants compared to their homeland, was hunting wild animals in the forest. The forest of the nearby Northern Sierra Madre Natural Park, a national protected area, and the secondary forest adjoining it, are home to a variety of wildlife of which wild pigs, deer, monitor lizards and monkeys are the most important game animals (Figures 18 \& 19). The rivers flowing westward from the mountains to the Cagayan River also contained various species of freshwater fish, including introduced tilapia, which was originally only grown in fishponds. Collection of non-timber forest products such as rattan, bamboo, and honey could generate cash income. In addition to the protein obtained through hunting and fishing, most of the Ifugao families also raise a few chickens and they may have a few pigs in their backyard that are reserved for special occasions (Figure 20). 
Figure 18 : Ifugao with spear. An Ifugao man demonstrating how to use a spear for hunting wild pig

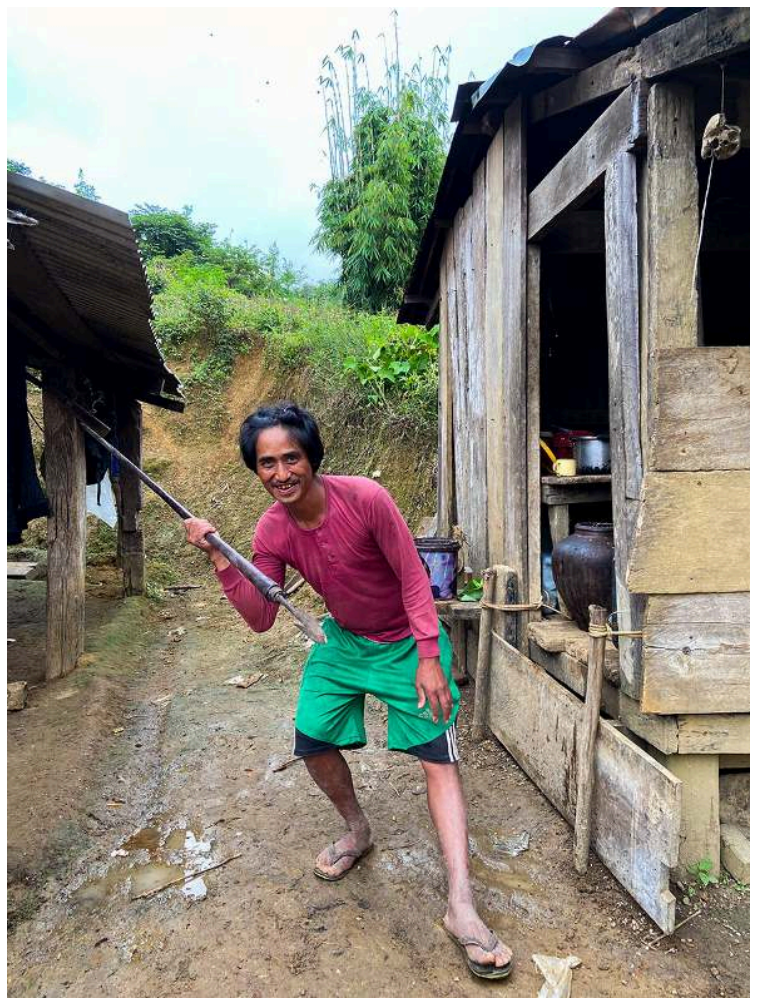

(c) M. van Weerd

Figure 19 : Skulls of Philippine warty pigs, Long-tailed macaques and Philippine deer are kept at the house of an Ifugao hunter

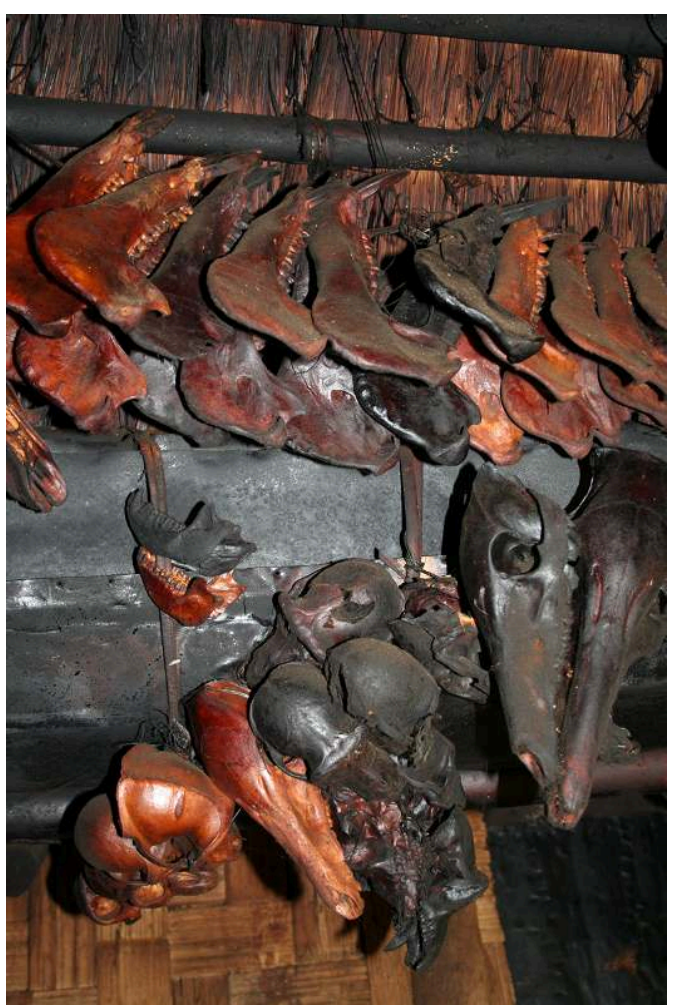

(c) G. Persoon 


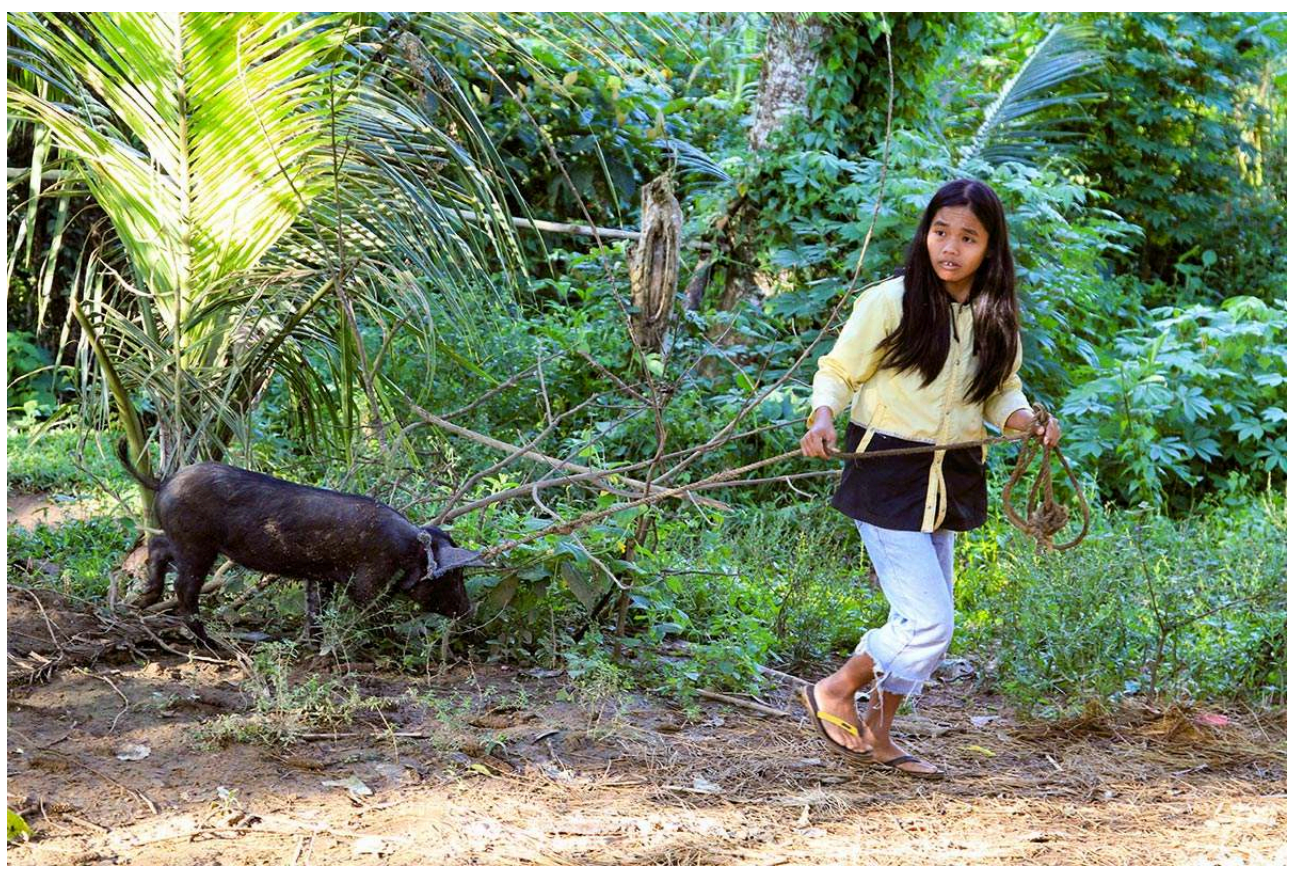

(c) G. Persoon

In comparison with their home area the social environment of the Ifugao living in the Sierra Madre foothills is quite different. Some of the small settlements are predominantly Ifugao but in some larger hamlets and villages the Ifugao are just one of various ethnic groups. Defining the interaction with members of other ethnic groups is becoming more important. Some other immigrants are also from the Cordillera, such as the Tinguian or the Kalinga. But there are also quite a few Ilocano from the northwestern Luzon or people from the dominant ethnic groups in the Province of Isabela such as the Ybanac, or the Isneg. From the interviews it became very clear that the people are still proud to call themselves Ifugao. They are also respected by members of the other ethnic groups for their farming skills and knowledge and their hard work. In daily interaction they continue to use their native language, while most of them also master Ilocano, the lingua franca in Cagayan valley, in addition to Tagalog, the official national language. Most of the children are sent to local schools in Isabela but some families decide to send their children to relatives in Ifugao Province for education, as the distance from the small settlements to the first small town with schools is simply too big for children to travel daily.

Many people also often travel back and forth between Ifugao homeland and settlements in the Sierra Madre foothills. They do so for family affairs like marriages, funerals or other crucial moments. Often they are visited by relatives and friends from Ifugao who may help in agricultural activities or for social purposes. With the growth of the settlements over time, the social life of the Ifugao becomes less oriented towards the homeland. Increasingly, youngsters find wedding partners inside their own or nearby Ifugao settlements. Friends and relatives may come over for these occasions, which are celebrated in a traditional manner with their Ifugao customs, music and dances, including the gong. 

They belong to a large number of different churches. Some of them are Catholics, others are Jehovah's Witnesses, Methodists, Pentecostals, or so-called Born-again Christians. Iglesia ni Christo is another popular protestant church among the Ifugao, as in the rest of the Philippines. Many people are hesitant to talk about their traditional beliefs, which are now thought to be outdated and refer to the period when they were still " pagans ». They no longer make or keep wooden statues, or bulul, as images of the rice gods or of the granary guardians and which were used in rituals related to rice cultivation. On the other hand, many Ifugao still believe to a certain extent in spirits living in their environment. Large balete trees (strangler fig trees) and caves are thought to be dwelling places for various types of supernatural beings (anito). For any more in-depth discussion about the traditional beliefs and rituals, the migrant farmers referred to their homeland, where such beliefs and practices are said to be still strong.

In terms of ethnicity, Ifugao Province is a rather homogeneous area. Positions at all levels of the administrative structure, from the governor down to the local village heads, are occupied by members of the same ethnic group. This situation is quite different in the Sierra Madre. Here the recently established settlements at the forest fringe are relatively marginal areas of larger municipalities that have for a long time been dominated by members of other ethnic groups. The Ifugao do not play an active role in the political life of the municipalities, apart from being voters at times of elections. Many of these settlements are simply too small to have community facilities such as schools, polyclinics or what is called a barangay hall. The people are forced to travel to the larger villages or small towns along the Cagayan River.

\section{The world of water: visiting the Ifugao homeland}

Following the positive experiences with the 2007 summer course, from 2011 - 2020, an annual one-month field course was jointly organized by Leiden University and Isabela State University for 30 students of both universities with various disciplinary backgrounds. No longer exclusively focused on Ifugao migrants, this course studied various issues with environmental sustainability and water management (the water course). But in the tradition of Conklin, field immersion and participatory observations were a very important part of the learning experience in this course. Fieldwork always started in the village of Balete in the foothills of the Sierra Madre, a small settlement of Ifugao farmers where students were introduced to the life of the migrant farmers and where they were trained in field observations and interviewing (for an overview of the first five years see Van Weerd et al. 2016).

At the end of each year's course, the group of students visited the Ifugao homeland and the spectacular rice terraces of the village of Batad in particular. Apart from being a three-day fun ending of the intensive field course, the Ifugao excursion was also meant to be an opportunity to learn more about indigenous water management systems, agriculture and Ifugao culture. In Batad, the group stayed in the simple but beautifully located pension of the resident Addug family. Members of the family guided the students through the rice terraces, explaining their history and functioning. Students then went around, observing and talking with residents to explore and understand Ifugao life.

Revue d'ethnoécologie, 20 | 2021 
In September 2011, typhoon Nesat (Philippine name Pedring) caused widespread damage in northern Luzon. In Batad, a huge landslide destroyed many of the stone walls, carving a scar from the top of the rice terraces through the middle section of the hill slope (Figures 21 \& 22). As families are dependent on each other for an uninterrupted water-flow, such damages would normally be repaired by workers from all families under the cooperative bachang and ubbu (brotherhood and sisterhood) systems. When the water course group visited the site again in January 2012, the students learned that the bachang/ubbu system no longer functioned well, as many young men and women had left Batad to seek fortune elsewhere, for example in Isabela Province, where agriculture was much easier and more profitable. Nowadays, the remaining families take care of their own terraces, but no longer work cooperatively to restore large-scale damages to terraces. In the general spirit of Philippine bayanihan (working together for a common goal without expecting a reward), the water course group has worked every year during part of their stay to help restore one particular row of terraces in Batad. Under the guidance of the Addug family, students learn how the terraces are built, and experience personally what a tremendous task it is to maintain them (Figure 23).

Figure 21 : Conklin Batad. Steeply terraced and settled slopes in Batad

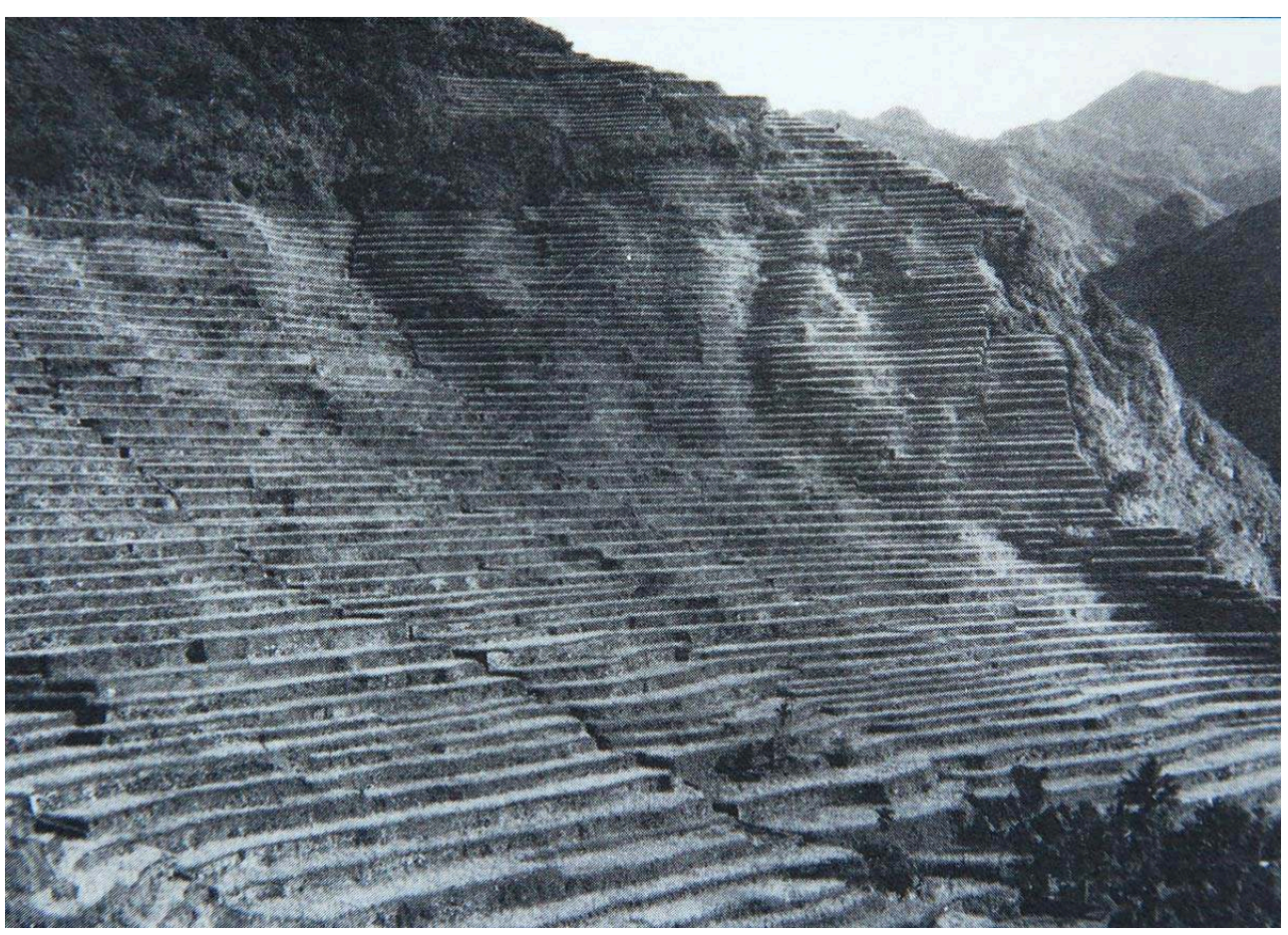

(c) Conklin 1980, photo 21. Picture taken sometime in the 1970s 
Figure 22 : Batad 2012. The same rice fields showing the damages after the hurricane in 2012

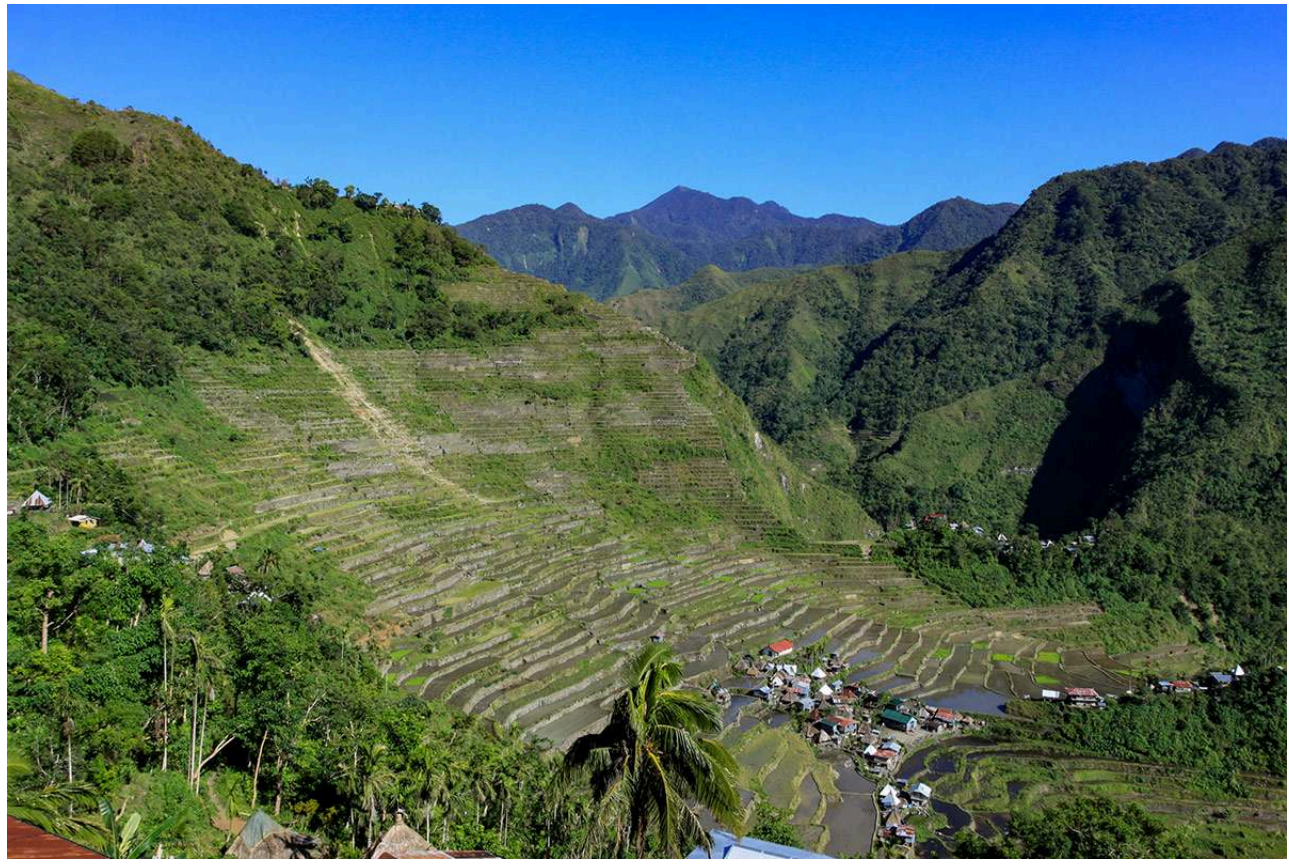

(c) M. van Weerd

Figure 23 : Students of the water course are helping to restore the damaged stone-walls in Batad

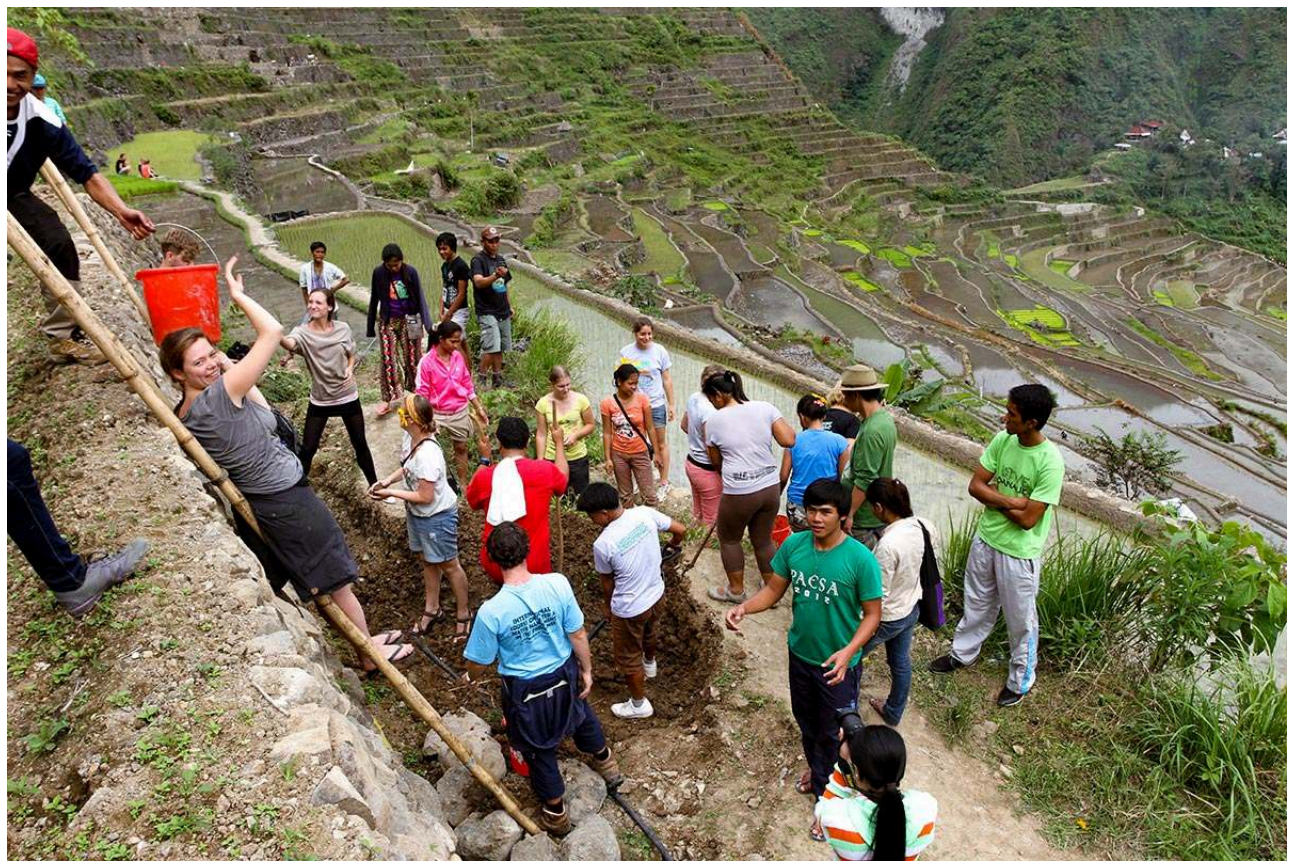

(c) M. van Weerd

41 In recent years, another link exists between the water course and Conklin's work. Conklin understood early on that aerial photography and maps provide important information about patterns of land use and change, especially in a complicated landscape such as the Ifugao homeland (Conklin 1967). Eventually this led to the publication of his Atlas. The recent development of consumer drones greatly facilitates 
and makes affordable the use of aerial images in field research (Figure 24). In the water course, aerial images generated with drones are now regularly used to study land use, land-use change and impacts of deforestation and of typhoons. High-quality aerial photographs of all the different field ponds, with their different shapes, sizes and connections, enable a much better understanding of the organization of the Batad rice terraces, including the impact of typhoon Nesat on water flows. In Batad, this drew the attention of the elder Addug, who also saw possibilities to solve land ownership issues using drone-generated aerial photography, and better understand the impact of migration and neglect of pond field maintenance on the overall functioning of the rice terraces.

Figure 24 : An aerial image of Batad, taken with a drone

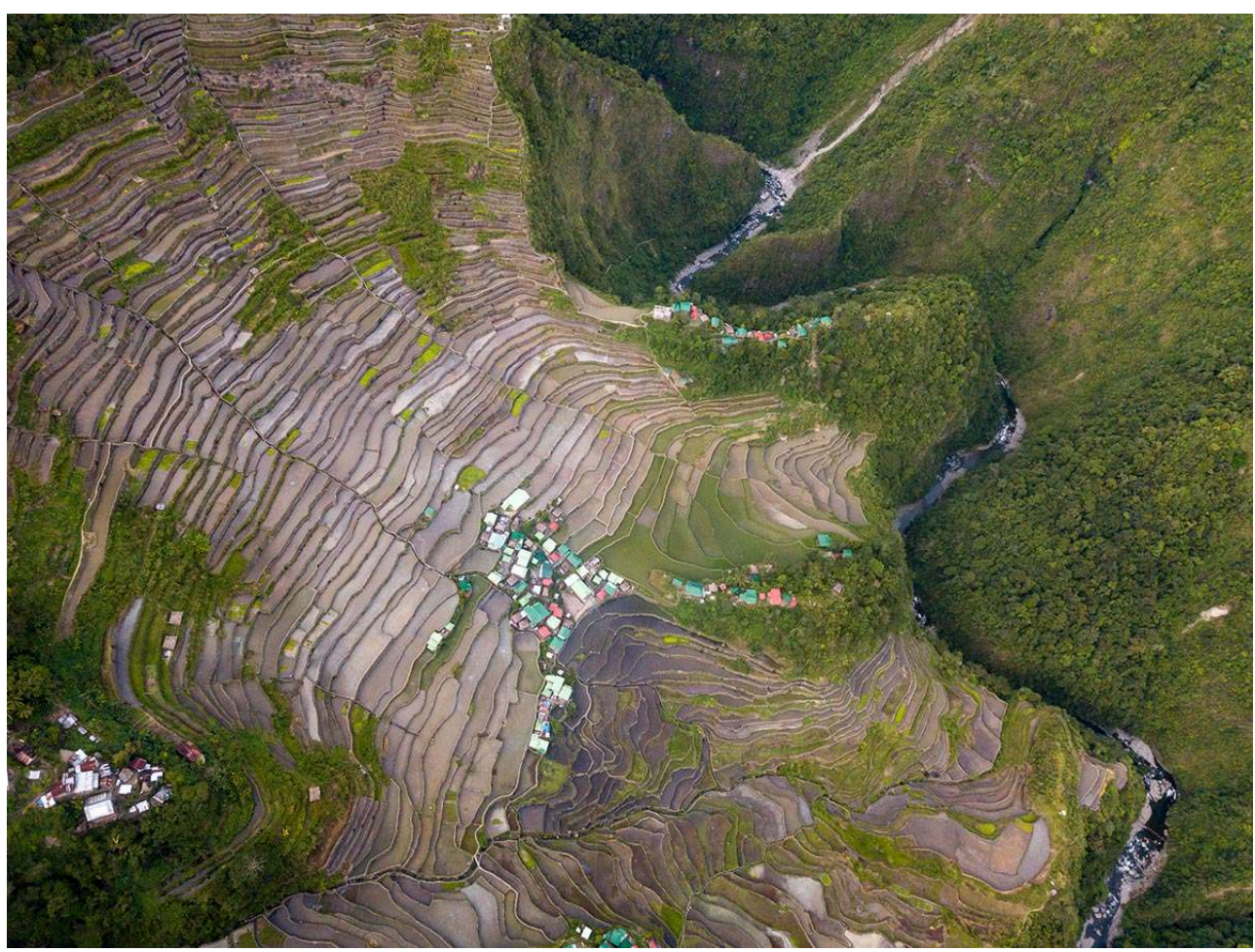

(c) M. van Weerd

During every visit of the water course, photographs are made of the Batad rice terraces, in recent years including aerial images. These photographs show the changes in the terraces, and the progress of restoration and degradation. As a result of restoration activities, the considerable damage by typhoon Nesat in 2012 is no longer visible on photographs taken in 2018. However, compared to a photograph in Conklin's Atlas, the effects of neglect of several terraces are clearly visible. In the early 1970s all terraces were well-maintained and in use. In 2018, a considerable number of terraces were overgrown with weeds and no longer used. Conklin's living landscape is alive and changing, but not necessarily in the direction that Unesco and the proponents and donors of the large-scale World heritage restoration projects desire. Meanwhile, a new landscape of irrigated rice fields is developing in the foothills of the Sierra Madre mountains, perhaps not as spectacular, but definitely more profitable and easier to maintain, by the same people who have left Batad and other villages of the Ifugao homeland. 


\section{A source of inspiration} out by their teacher. Others write books or research articles that turn out to be works of great importance and that are referred to as key publications in their fields and that are cited over and over again. That may be because of others supporting the author's ideas or perspectives, or because the publications serve as targets against which contrasting ideas gain in relevance or insight. And there are also authors who publish books, chapters in edited volumes or articles that are of great importance but that do not raise a lot of controversy in terms of the theoretical suggestions they put forward, on the basis of the methods they apply or because of critical ethical issues. But such work is often of great importance because of its influence on the future research agenda for a number of topics, or because it sets new standards for the quality of the research work to be undertaken. This type of work is highly inspirational for students and colleagues working in similar fields. Conklin's writings, which are referred to quite often but not in exceptionally high numbers, certainly belongs to this type of work.

In Harold Conklin's obituary written shortly after his death, Roy Ellen noted that it is quite remarkable that, given the fact that Conklin wrote relatively little in the way of conventional monographs or journal papers, he has been influential in many intellectual fields beyond anthropology, in which he was also a pioneer (Ellen 2016, see also Remme 2021). Some of his publications are also not easily accessible or, like his Atlas, have long been out of print. His impact or influence has mainly been achieved through the quality, precision and level of detail of his ethnographic writing and not by proposing new and challenging grand theories. Theoretical ideas were often hidden in his descriptions. In his writings he always stressed the ethnographic nature of his work. The use of a multitude of methods derived from various disciplines was aimed at writing higher-quality ethnography. He also was not known for using his expertise for directing his research output to address wider audiences of government officials or policy makers. It seems as if he relied completely on the quality of his writings to convince these actors of the nature and value of the agricultural practices he described, and left them to draw the implications-which clearly followed from his demonstrations-that would help them avoid proposing policies based on false or inaccurate assumptions.

In short, through his approach to the study of the agro-ecological knowledge and practices of some ethnic groups in the Philippines, Conklin became a pioneer in new fields of ethnography and anthropology. His intensive fieldwork, employing a great variety of methods that were at the time highly innovative, generated information on the basis of which he could write impressive publications, in particular those on Hanunóo shifting cultivation, and on the Ifugao rice terraces. These set new standards for researchers working not only on similar topics but also for anthropology in general. In doing so, he provided a great deal of inspiration for students and researchers to build on in a creative manner in the directions that Conklin laid out. The inspiration is evident not only from the wide and explicit recognition that he has received by many researchers, but also implicitly: present-day standards for high quality ethnography, including the wide range of methods and research tools, have been positively influenced by him through the work of a new generation of teachers and researchers 
who have trained and supervised the younger generation, who may not even be aware of the impact of Conklin as one of the key figures in the discipline.

The authors thank Doyle McKey and Eric Nieuwenhuizen for their useful comments.

\section{BIBLIOGRAPHY}

Acadabo S. 2012 - Taro before rice terraces: implications of radiocarbon determinations, ethnohistoric reconstructions, and ethnography in dating the Ifugao terraces. Senri Ethnological Studies $78: 285-305$.

Acadabo S. 2013 - Defining Ifugao social organization: « House », Field and self-organizing principles in the Northern Philippines. Asian Perspectives 52 (2) :161-189.

Acadabo S. 2015 - Antiquity, archaeological processes, and highland adaptation: the Ifugao Rice Terraces. Quezon City, Ateneo de Manila University Press.

Acabado S.J., Koller M., Liu C.H., Lauer A., Farahani A., Barretto-Tesoro G., Reyes M.C., Martin J.A. \& Peterson J.A. 2019 - The short history of the Ifugao Rice Terraces: a local response to the Spanish Conquest. Journal of Field Archaeology 44 (3) : 195-214.

Aquino D. 2004 - Resource management in ancestral land. The Bugkalots in Northeastern Luzon. Leiden, PhD dissertation.

Aspe N. 2020 - Field Guide: Earthworms in Heirloom Rice Fields of the Philippine Cordillera and Their Integrated Management. Los Baños, IRRI.

Bantayan N.C., Calderon M., Dizon J., Sajise A.J. \& Salvador M.G. 2012 - Estimating the extent and damage of the UNESCO World Heritage Sites of the Ifugao Rice Terraces, Philippines. Journal of Environmental Science and Management 15 (1) : 1-5.

Bernardo E.C. \& Snelder D.J. (Ed.) - Co-managing the environment. The natural resources of the Sierra Madre Mountain Range. Leiden/Cabagan, CVPED.

Brokensha D., Warren D.M. \& Werner O. (Ed.) 1980 - Indigenous knowledge systems and development. Lanham, University Press of America.

Buenafe-Ze M., Minter T. \& Telan W.G. 2016 - Against mining and the need for mining: conundrums of the Agta from the Northeastern Philippines. Journal für Entwicklungspolitik 32 (4) : 67-91.

Cagat K.A.D. 2018 - Mixed views on the Philippines' Ifugao Rice Terraces: 'Good' versus 'beautiful' in the management of a UNESCO World Heritage site. Journal of Southeast Asian Studies 49 (1): 84-104.

Cairns M.F. (Ed.) 2007 - Voices from the Forest. Integrating Indigenous Knowledge into Sustainable Upland Farming. London, Routledge.

Cairns M.F. (Ed.) 2015 - Shifting Cultivation and Environmental Change. Indigenous Peoples, Agriculture and Forest Conservation. London, Routledge. 
Cairns M.F. (Ed.) 2017 - Shifting cultivation policies. Balancing environmental and social sustainability. Wallingford/Boston, CABI.

Cairns M.F. (Ed.) in press - Farmer Innovations and Best Practices by Shifting Cultivators in Asia-Pacific. Wallingford/Boston, CABI.

Calderon M., Dizon J.T., Sajise A.J., Andrada R.T., Bantayan N.C. \& Salvador M.G. 2009 - Towards the development of a sustainable financing mechanism for the conservation of the Ifugao Rice Terraces in the Philippines. Singapore, EEPSEA.

Conklin H.C. 1954a - The relation of the Hanunóo culture to the plant world. New Haven, Yale University (PhD dissertation).

Conklin H.C. 1954b - An ethnoecological approach to shifting agriculture. Transactions of the New York Academy of Sciences 17 (2) : 133-142.

Conklin H.C. 1957 - Hanunóo agriculture. A report on an integral system of shifting cultivation in the Philippines. Rome, FAO.

Conklin H.C. 1961 - The study of shifting cultivation. Current Anthropology 2 (1) : 27-91.

Conklin H.C. - Ethnographic research in Ifugao. Transactions of the New York Academy of Sciences, ser. II, 30 (1) : 99-121. (Also published in a slightly modified version In : Vogt E.Z. (Ed.) 1974 Aerial Photography in Anthropological Field Research : 146-160. Cambridge, Harvard University Press.)

Conklin H.C. 1968 - Ethnography. In : International encyclopedia of the social sciences, 5 : 172-178. New York, Macmillan and Free Press.

Conklin H.C. 1980 - Ethnographic Atlas of Ifugao. A study of environment, culture, and society in Northern Luzon. New Haven, Yale University Press.

Conklin H.C. 1998 - Language, culture, and environment: my early years. Annual Review of Anthropology 27 : xiii-xxx.

DENR (Department of Environment and Natural Resources) 2008 - The Ifugao Rice Terraces. Philippine Project Framework. Manila, DENR.

Dove M.R. 2007 - Commentary: kinds of fields. In : Kuipers J.C. \& McDermott R. (Ed.) Fine description: Ethnographic and linguistic essays : 411-427. New Haven, Yale University Press. Dove M.R. 2016 - Harold C. Conklin (1926 2016). American Anthropologist 119 (1) : 174-182.

Dove M.R. \& Kirch P.V. 2018 - Harold C. Conklin, 1926-2016. A Biographical Memoir. National Academy of Sciences.

Druguet A. 2010 - De l'invention des paysages à la construction des territoires. Les terrasses des Ifugao (Philippines) et des Cévenols (France). PhD thesis, Musée National d'Histoire Naturelle. Paris, MNHN.

Ellen R., Parkes P. \& Bicker A. (Ed.) 2000 - Indigenous environmental knowledge and its transformations. Critical anthropological perspectives. Amsterdam, Harwood Academic Publishers.

Ellen R. 2016 - Harold Colyer Conklin, 1926 - 2016. An appreciation. Obituaries, Royal Anthropological Institute.

Frake C.O. 2007 - Fine description. In : Kuipers J.C. \& McDermott R. (Ed.) Fine description: Ethnographic and linguistic essays : ix-xvii. New Haven, Yale University Press.

Geertz C. 2007 - Commentary: on paying attention. In : Kuipers J.C. \& McDermott R. (Ed.) Fine description: Ethnographic and linguistic essays : 27-30. New Haven, Yale University Press. 
Glover D. \& Stone G.D. 2017 - Heirloom rice in Ifugao: an 'anti-commodity' in the process of commodification. The Journal of Peasant Studies 45 (4) : 776-804.

Kuipers J.C. \& McDermott R. (Ed.) 2007 - Harold C. Conklin Fine description: Ethnographic and linguistic essays. New Haven, Yale University Press.

Lévi-Strauss C. 1962 - La pensée sauvage. Paris, Librairie Plon.

Masipiqueña A.B., Van Weerd M. \& Udto R.G. (Ed.) 2009 - Changing landscapes. Proceedings of the sixth international conference on environment and development. Cabagan/Leiden, CVPED.

Minter T. 2010 - The Agta of the Northern Sierra Madre. Livelihood strategies and resilience among Philippine hunter-gatherers. Leiden, PhD dissertation.

Pasicolan P.N. 1996 - Growing trees on different grounds. An analysis of local participation on contract reforestation in the Philippines. Leiden, PhD dissertation.

Persoon G.A., Masipiqueña A., Van der Ploeg J., Masipiqueña M. \& Van Weerd M. (Ed.) 2009 Crossing Boundaries. Celebrating 20 years of environmental research in Cagayan Valley and Sierra Madre. Leiden/Cabagan, CVPED.

Remme J.H.Z. 2021 - Harold C. Conklin: Atlas of multispecies relations in Ifugao. Ethnos 86 (1) : 93-113.

Santiago J.O. \& Buot I.E. 2018 - Conceptualizing the socio-ecological resilience of the Chaya rice terraces, a socio-ecological production landscape in Mayoyao, Ifugao, Luzon Island, Philippines. Journal of Marine and Island Cultures 7 (1) : 107-126.

Scott W.H. 1974 - The discovery of the Igorots. Spanish contacts with the pagans of Northern Luzon. Quezon City, New Day Publishers.

Snelder D.J. \& Bernardo E. (Ed.) 2005 - Comanagement in practice. The challenges and complexities of implementation in the Northern Sierra Madre Mountain Range. Quezon City, Ateneo de Manila UP.

Unesco/World Heritage Centre 2012 - Better conservation in Pakistan and the Philippines allow Committee to remove two sites from World Heritage List in Danger. (https://whc.Unesco.org/en/news/ $891 /$ )

Unesco/World Heritage Centre 2021 - Rice Terraces of the Philippine Cordilleras (https://whc.org/ en/list/722/)

Van den Top G.M. 1998 - The social dynamics of deforestation in the Sierra Madre, Philippines. Leiden, PhD thesis.

Van den Top G.M. \& Araño R. (Ed.) 1992 Forestry for peole and nature. Field research and theory on environment and development in the Cagayan Valley, Philippines. Leiden/Cabagan. CVPED.

Van der Ploeg J. 2013 - Swallowed by a cayman. Integrating cultural values in Philippine crocodile conservation. Leiden, $\mathrm{PhD}$ dissertation.

Van der Ploeg J., Masipiqueña A.B. \& Bernardo E.C. (Ed.) 2003 - The Sierra Madre Mountain Range. Global relevance, local realities. Tuguegarao, Golden Press.

Van der Ploeg J. \& Masipiqueña A.B. (Ed.) 2005 - The future of the Sierra Madre. Responding to social and ecological challenges. Tuguegarao, Golden Press.

Van der Ploeg J., Persoon G.A. \& Masipiqueña M.D. (Ed.) 2007 - Ifugao migrants in and around the Northern Sierra Madre Natural Park. Leiden/Cabagan, CML/CVPED. 
Van der Ploeg J. \& Persoon G.A. 2017 - Figments of fire and forest: shifting cultivation policy in the Philippines and Indonesia. In : Cairns M. (Ed.) Shifting cultivation policies: Balancing environmental and social sustainability. Wallingford/Boston, CABI : 3-26.

Van Weerd M. \& Van der Ploeg J. 2012 - The Philippine Crocodile: Ecology, Culture and Conservation. Cabagan, Mabuwaya Foundation.

Van Weerd M., Taggueg J., Luning S., Masipiqueña M., Kok R., Gatan-Balbas M., Osterhaus-Simic N. \& Persoon G.A. (Ed.) 2016 - The World of Water. The international course on water use and management in Cagayan Valley, The Philippines (2011-2015). Leiden, Leiden University.

Warren D.M., Slikkerveer L.J. \& Brokensha D. (Ed.) 1995 - The cultural dimension of development. Indigenous knowledge systems. London, Intermediate Technology Publications.

\section{ABSTRACTS}

Harold C. Conklin (1926-2016) is without doubt one of the key figures in ethnobotany and environmental anthropology. His work is admired for, among other qualities, its precision and its level of «fine description ». In particular, his pioneering studies on shifting cultivation have changed the general perspective on this way of land use. His Ethnographic Atlas of Ifugao (1980) is still a landmark of ethnographic fieldwork, combining a wide range of methods, including sophisticated cartography.

The focus of this atlas was on the culture of Ifugao farmers in their home area in the Cordillera Mountains on the island of Luzon in the Philippines. In recent decades, thousands of Ifugao farmers have left their home area and migrated eastwards to the Sierra Madre Mountains in the northeastern part of Luzon, across Cagayan Valley. They have done so for various reasons but land shortage is certainly one of them. In the foothills of the Sierra Madre, accessible arable land became available after large-scale commercial logging operations.

In this article we will draw attention to the relevance of Conklin's work before describing how the Ifugao farmers, with their extensive knowledge and experience, have been able to turn this new area into a highly productive environment, combining wet rice fields with upland agriculture. The research is based on fieldwork that was done over several years with Filipino, Dutch and other international students in the context of a long-standing cooperation project between Isabela State University in the Philippines and Leiden University (Netherlands).

Harold C. Conklin (1926-2016) est sans aucun doute une figure incontournable de l'ethnobotanique et de l'anthropologie de l'environnement. Son travail est admiré pour sa précision et son niveau de «description fine », entre autres qualités. Plus particulièrement, ses études pionnières sur la culture itinérante ont changé la perspective générale sur ce mode d'utilisation des terres. Son Ethnographic Atlas of Ifugao (1980) demeure une référence pour le travail de terrain ethnographique, présentant à la fois un large éventail de méthodes et une cartographie sophistiquée.

Cet atlas était centré sur la culture des agriculteurs ifugao dans leur région d'origine - les montagnes de la cordillère sur l'île de Luzon aux Philippines. Au cours des dernières décennies, des milliers d'agriculteurs ifugao ont quitté leur région d'origine et ont migré vers l'est en direction des montagnes de la Sierra Madre au nord-est de Luzon, de l'autre côté de la vallée de Cagayan. Ils l'ont fait pour diverses raisons, mais la pénurie de terres est certainement l'une d'entre elles. Sur les contreforts de la Sierra Madre, des terres arables accessibles sont devenues disponibles suite à des opérations d'exploitation forestière commerciale à grande échelle.

Dans cet article, nous soulignerons la pertinence des travaux de Conklin avant de montrer comment les agriculteurs d'Ifugao, grâce à leurs connaissances approfondies et leur expérience, 
ont pu transformer cette nouvelle zone en un environnement très productif, associant rizières humides et agriculture de montagne. La recherche est fondée sur un travail de terrain mené durant plusieurs années avec des étudiants philippins, néerlandais et d'autres nationalités, dans le cadre d'un projet ancien de coopération entre l'Isabela State University aux Philippines et l'Université de Leiden aux Pays-Bas.

\section{INDEX}

Keywords: Harold C. Conklin, shifting cultivation, Ifugao rice terraces, Ifugao farmers, The Philippines, Sierra Madre Mountains

Mots-clés: Harold C. Conklin, culture itinérante, rizières en terrasses, agriculteurs, Ifugao, Philippines, Sierra Madre

\section{AUTHORS}

\section{GERARD A. PERSOON}

Professor of Environment and Development (em.), Institute of Cultural Anthropology, Leiden University, Wassenaarseweg 52, P.O. Box 9555, 2300 RB Leiden, The Netherlands. Email address persoonga@fsw.leidenuniv.nl, Tel. +31 715276826

\section{JAN VAN DER PLOEG}

Director STINAPA, Bonaire. Email address: vanderploegjan@hotmail.com

\section{MERLIJN VAN WEERD}

Director Mabuwaya Foundation; Lecturer, Institute of Cultural Anthropology, Leiden University, Wassenaarseweg 52, P.O. Box 9555, 2300 RB Leiden, The Netherlands. Email address:

merlijnvanweerd@yahoo.com 